\title{
Stratigraphy and sedimentology of a basement-onlapping shallow marine sandstone succession, the Charcot Bugt Formation, Middle-Upper Jurassic, East Greenland
}

\author{
Michael Larsen, Stefan Piasecki and Finn Surlyk
}

\begin{abstract}
A rocky shore developed in early Middle Jurassic times by transgression of the crystalline basement in Milne Land at the western margin of the East Greenland rift basin. The basement is onlapped by shallow marine sandstones of the Charcot Bugt Formation, locally with a thin fluvial unit at the base. The topography of the onlap surface suggests that a relative sea-level rise of at least $300 \mathrm{~m}$ took place in Early Bathonian - Middle Oxfordian times. The sea-level rise was punctuated by relative stillstands and falls during which progradation of the shoreline took place.

Palynological data tied to the Boreal ammonite stratigraphy have greatly improved time resolution within the Charcot Bugt Formation, and the Jurassic succession in Milne Land can now be understood in terms of genetically-related depositional systems with a proximal to distal decrease in grain size. The sequence stratigraphic interpretation suggests that translation of the depositional systems governed by relative sea-level changes resulted in stacking of sandstone-dominated falling stage deposits in the eastern, basinwards parts of Milne Land, whereas thick, remarkably coarsegrained transgressive systems tract deposits formed along the western basin margin. The bulk of the Charcot Bugt Formation consists of stacked sandstone-dominated shoreface units that prograded during highstands.

The overall aggradational to backstepping stacking pattern recognised in the Charcot Bugt Formation is comparable to that in the contemporaneous Pelion Formation of the Jameson Land Basin and in correlative units of the mid-Norway shelf and the Northern North Sea. We suggest that the long-term evolution of the depositional systems may have been controlled by long-term eustatic rise acting in concert with relative sea-level changes reflecting regionally contemporaneous phases of rift initiation, climax and gradual cessation of rifting.
\end{abstract}

Keywords: East Greenland, Milne Land, Bathonian-Oxfordian, Charcot Bugt Formation, Kap Leslie Formation, sedimentology, biostratigraphy, dinoflagellates, sequence stratigraphy, shallow marine, basement onlap, clinoform unit

M.L. \& S.P., Geological Survey of Denmark and Greenland, Geocenter Copenhagen, Øster Voldgade 10, DK-1350 Copenhagen K, Denmark. E-mail: mil@geus.dk

F.S., Geological Institute, University of Copenhagen, Geocenter Copenhagen, Øster Voldgade 10, DK-1350 Copenbagen K, Denmark.

The Lower Bathonian - Middle Oxfordian Charcot Bugt Formation is a marginal marine clastic wedge, which has received relatively little attention in the past due to its remote position and its coarse-grained, mostly unfossiliferous nature (Bay 1895; Aldinger 1935; Håkansson et al. 1971; Callomon \& Birkelund 1980). The aims of this study were to combine biostratigraphic and sedimentological data into a coherent depositional and sequence stratigraphic model for the Charcot Bugt Formation in Milne Land. In previous studies, the bio- 


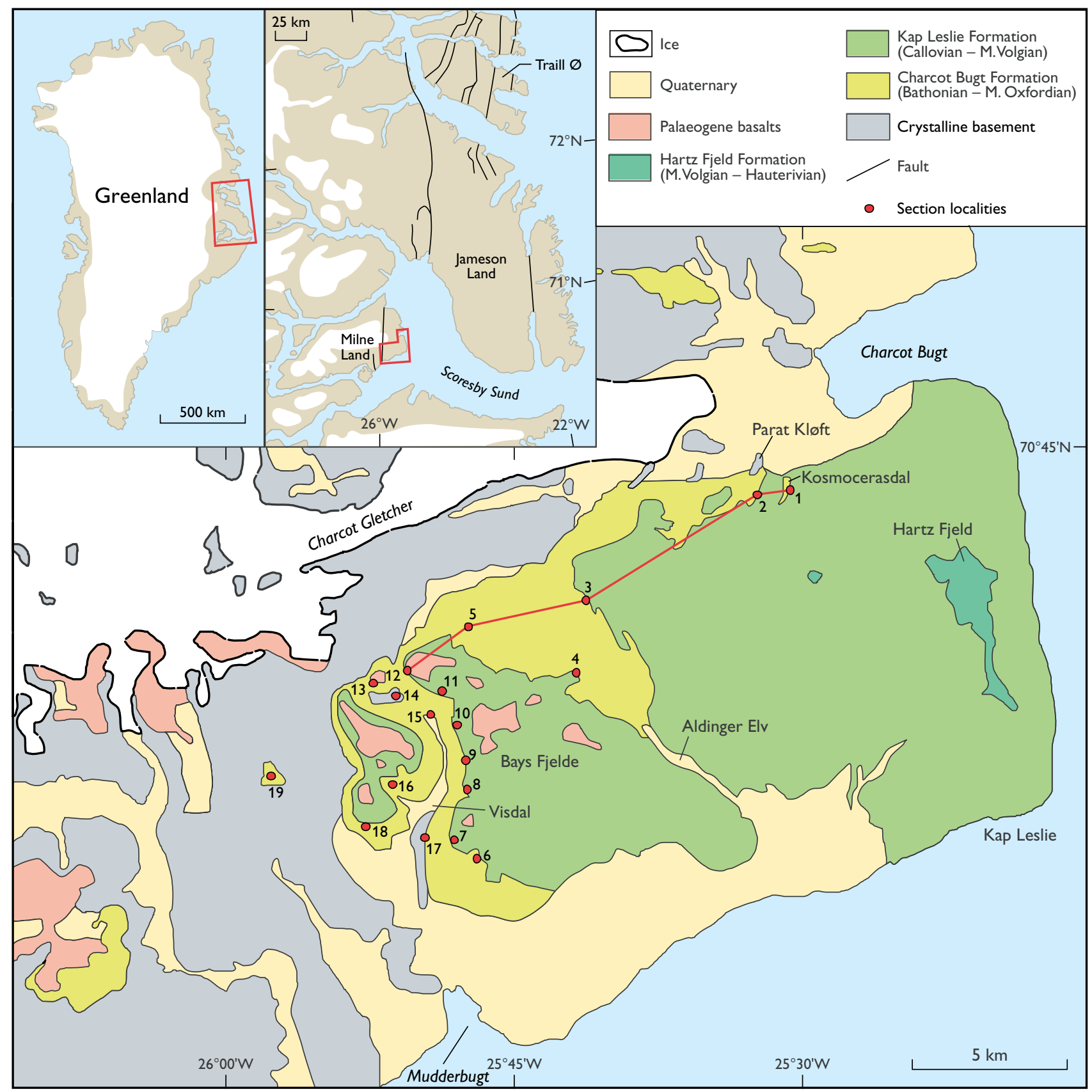

Fig. 1. Map showing the distribution of Mesozoic sediments in Milne Land, East Greenland. The sandstones of the Bathonian - Middle Oxfordian Charcot Bugt Formation onlap Caledonian crystalline basement and are overlain by silty mudstones of the Middle Callovian - Middle Volgian Kap Leslie Formation; the boundary between the two formations is diachronous, younging to the west. Middle Volgian - Hauterivian sandstones of the Hartz Fjeld Formation are exposed to the east. The succession is unconformably overlain by Palaeogene flood basalts. Inset maps indicate the location of Milne Land, Jameson Land and Traill $\varnothing$ in East Greenland; the red line indicates the log panel in Fig. 18.

stratigraphy was based solely on macrofossils; herein we present new correlations combining the existing ammonite stratigraphy with dinoflagellate data. These new biostratigraphic data also allow a better subdivision of the coarse-grained marginal marine sandstones.
Rocky shorelines are spectacular but rarely described features in the rock record. The onlap contact between the former subaerially exposed rock surface and the marine strata allows quantification of the relative sealevel changes during the Middle Jurassic. Facies analy- 


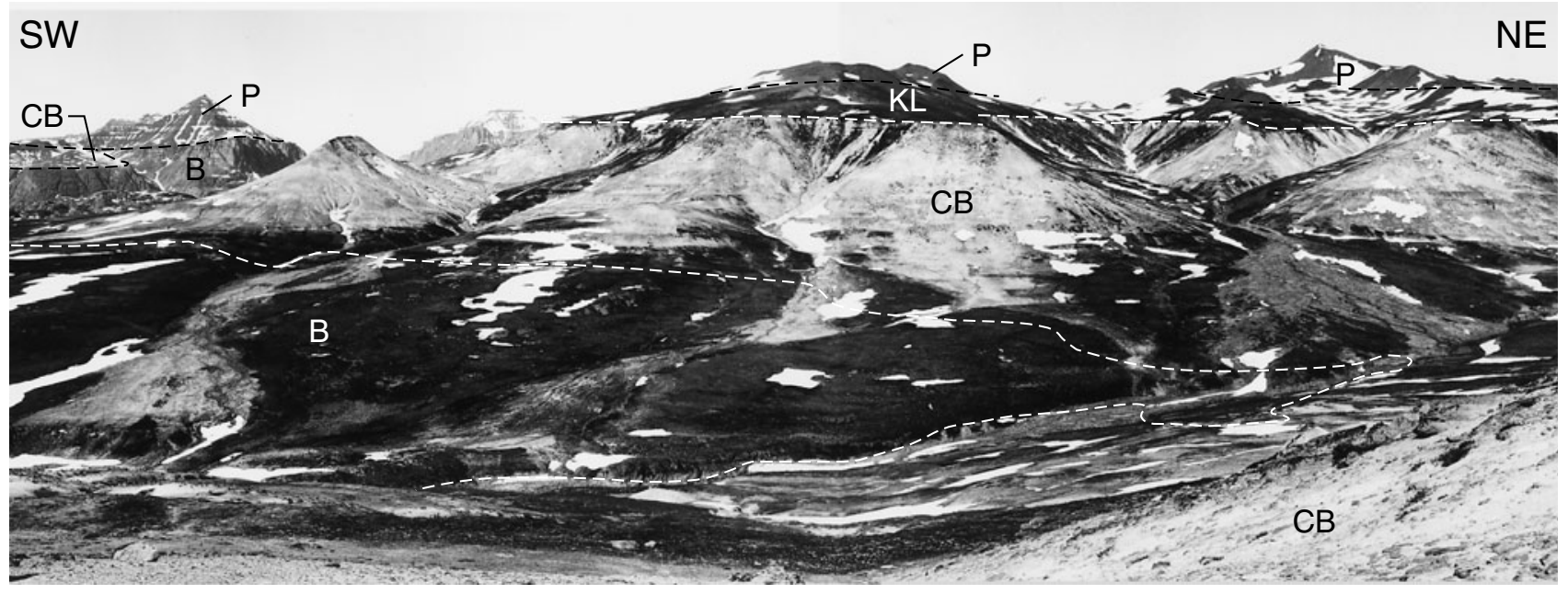

Fig. 2. Outcrop of the Charcot Bugt (CB; c. $100 \mathrm{~m}$ thick) and Kap Leslie (KL) Formations at Visdal, viewed towards the north-west. Note the sharp boundary between the formations interpreted to represent a coincident sequence boundary and marine transgressive surface of erosion. The base of the Charcot Bugt Formation is a marine onlap surface and reflects the pre-Jurassic topography of the crystalline basement $(\mathbf{B})$. High peaks are formed of Palaeogene flood basalts (P).

sis provides the basis for interpretation of the depositional environments during an overall middle Jurassic sea-level rise that resulted in erosion of the former subaerially exposed area and the formation of unusually thick transgressive deposits. The giant-scale cross-sets that form the top of the Charcot Bugt Formation in Visdal were first described by Callomon \& Birkelund (1980). Three-dimensional mapping of these cross-bedded units has revealed a complex internal upbuilding, each unit being composed of clinoform sets. It is suggested that the clinoforms formed by strong progradation of the clastic shoreline, probably in response to pulses of falling relative sea level.

\section{Geological setting}

The Late Palaeozoic - Mesozoic East Greenland rift basin is part of the larger rift complex between Greenland and the Baltic Shield that existed prior to the opening of the North Atlantic (Ziegler 1988; Doré 1991). Rift basin formation was initiated in Devonian times, and Late Permian through Mesozoic basin evolution was governed by cooling and thermal contraction punctuated by phases of extensional faulting, resulting in the

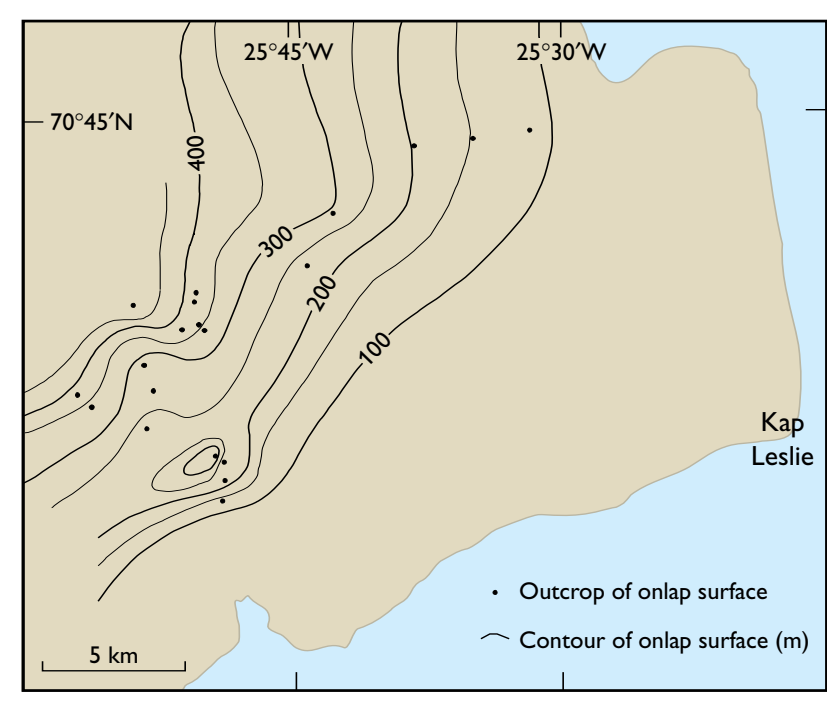

Fig. 3. Contour map of the crystalline basement - sediment boundary representing the topography of the onlap surface in Bathonian-Oxfordian times in Milne Land. The map is corrected for post-Jurassic regional tectonic dip of $3.5^{\circ}$ towards the southeast.

development of basin margin half-grabens (Surlyk et al. 1984, 1986; Surlyk 1990, 1991, 2003, this volume). The East Greenland continental margin was uplifted in Neogene times and now presents excellent exposures of a Mesozoic sedimentary succession deposited in an epicratonic rifted seaway.

During the Middle Jurassic, the Jameson Land Basin formed a north-south elongate embayment, c. $140 \mathrm{~km}$ wide and more than $400 \mathrm{~km}$ long. The Lower Bathonian - Middle Oxfordian Charcot Bugt Formation was deposited during a long-term transgression recognised throughout the East Greenland basin (Surlyk 1990, 1991, 2003 , this volume), and a high gradient rocky shore was 
formed along the faulted western basin margin (Fig. 1). In Milne Land, shallow marine sediments of the Charcot Bugt Formation onlap the irregular, south-east dipping surface of the Caledonian crystalline basement (Fig. 2; Larsen 1995). The orientation of the onlap surface has been corrected for post-Jurassic tilting of $3.5^{\circ}$ and can be shown to have risen $c$. $300 \mathrm{~m}$ over a distance of 8-15 $\mathrm{km}$ in an up-dip direction (Fig. 3). This corresponds to an average dip of the basement surface of $1-2^{\circ}$, but locally around basement highs the dip is up to $36^{\circ}$. The amount of relative sea-level rise is estimated by tracing the surface representing the contact between the former subaerially exposed basement and the onlapping marine deposits.

\section{Stratigraphy}

The main emphasis of previous studies of the Mesozoic of Milne Land was on the general stratigraphy (Bay 1895; Rosenkrantz 1929; Aldinger 1935), Late Jurassic ammonite biostratigraphy and lithostratigraphy (Spath 1935, 1936; Callomon \& Birkelund 1980; Birkelund et al. 1984; Birkelund \& Callomon 1985) and palynology (Piasecki 1979, 1980).

\section{Lithostratigraphy}

The $1 \mathrm{~km}$ thick Jurassic - Lower Cretaceous succession of Milne Land is subdivided into three formations (Callomon \& Birkelund 1980; Birkelund et al. 1984). The Lower Bathonian - Middle Oxfordian Charcot Bugt Formation forms the basal sedimentary unit, and consists of coarse-grained sandstones and conglomerates (Fig. 4). It is overlain by, and passes laterally into, mudstones and fine-grained sandstones of the Callovian Middle Volgian Kap Leslie Formation (Fig. 4). In the eastern part of Milne Land, shallow marine and deltaic sandstones of the Middle Volgian - Hauterivian Hartz Fjeld Formation overlie the Kap Leslie mudstones (Piasecki 1979, 1980; Birkelund et al. 1984; Surlyk et al. 1993). Palaeogene flood basalts unconformably overlie the Mesozoic succession.

\section{Charcot Bugt Formation}

In outcrop, the Charcot Bugt Formation reaches a maximum thickness of $195 \mathrm{~m}$ in the eastern part of Milne Land and thins towards the west. At Visdal (Fig. 1), the formation varies in thickness from $162 \mathrm{~m}$ in the south to $97 \mathrm{~m}$ in the north. The topographic relief of the underlying crystalline basement (Fig. 3) controls the general wedge-shaped geometry and local variations in thickness. The occurrence of progressively younger ammonites in the sediments immediately above the unconformity surface towards the west also reflects the onlapping nature of the formation (Fig. 4). The upper formation boundary is a strongly diachronous surface which youngs towards the west from the Early Callovian to the Late Oxfordian, as indicated by the ammonite and dinoflagellate stratigraphy (Fig. 4).

The formation is subdivided into the Visdal and Mudderbugt Members (Callomon \& Birkelund 1980). The Visdal Member forms the main part of the formation and consists of sandy conglomerates with clasts of local crystalline basement rocks overlain by medium- to coarse-grained sandstones with minor siltstone beds. The overlying Mudderbugt Member forms a south-eastwards thickening wedge of coarse-grained sandstones, up to $6 \mathrm{~m}$ thick, exposed only in the southern part of Visdal (Fig. 1, locality 6). It overlies the Visdal Member with a sharp, and in places erosional, lower boundary.

\section{Kap Leslie Formation}

The Lower Callovian - Middle Volgian Kap Leslie Formation is subdivided into eight members (Callomon \& Birkelund 1980; Birkelund et al. 1984). The Kosmocerasdal Member (Lower Callovian - Upper Oxfordian) is the lowest and consists of bioturbated sandy siltstones and fine-grained sandstones; it forms the offshore fine-grained correlative of the upper Charcot Bugt Formation (Fig. 4). The member has a maximum thickness of $170 \mathrm{~m}$ along the east coast of Milne Land and thins westwards (Callomon \& Birkelund 1980). In the southern part of Visdal, it is only about $10 \mathrm{~m}$ thick, although the exact position of the upper boundary in this area is difficult to establish (Callomon \& Birkelund 1980; Piasecki 1980). It is overlain by the Upper Oxfordian Aldinger Elv Member, which forms a wedgeshaped sandstone body thinning westwards from about $90 \mathrm{~m}$ on the east coast of Milne Land to a few metres at Bays Fjelde (Fig. 4; Fürsich \& Heinberg 1983). The Aldinger Elv Member is overlain by dark silty mudstones with abundant glauconitic levels, referred to the Bays Elv Member (Upper Oxfordian - Lower Kimmeridgian). The remainder of the Kap Leslie Formation was discussed thoroughly by Birkelund et al. (1984) and is not considered further here. 


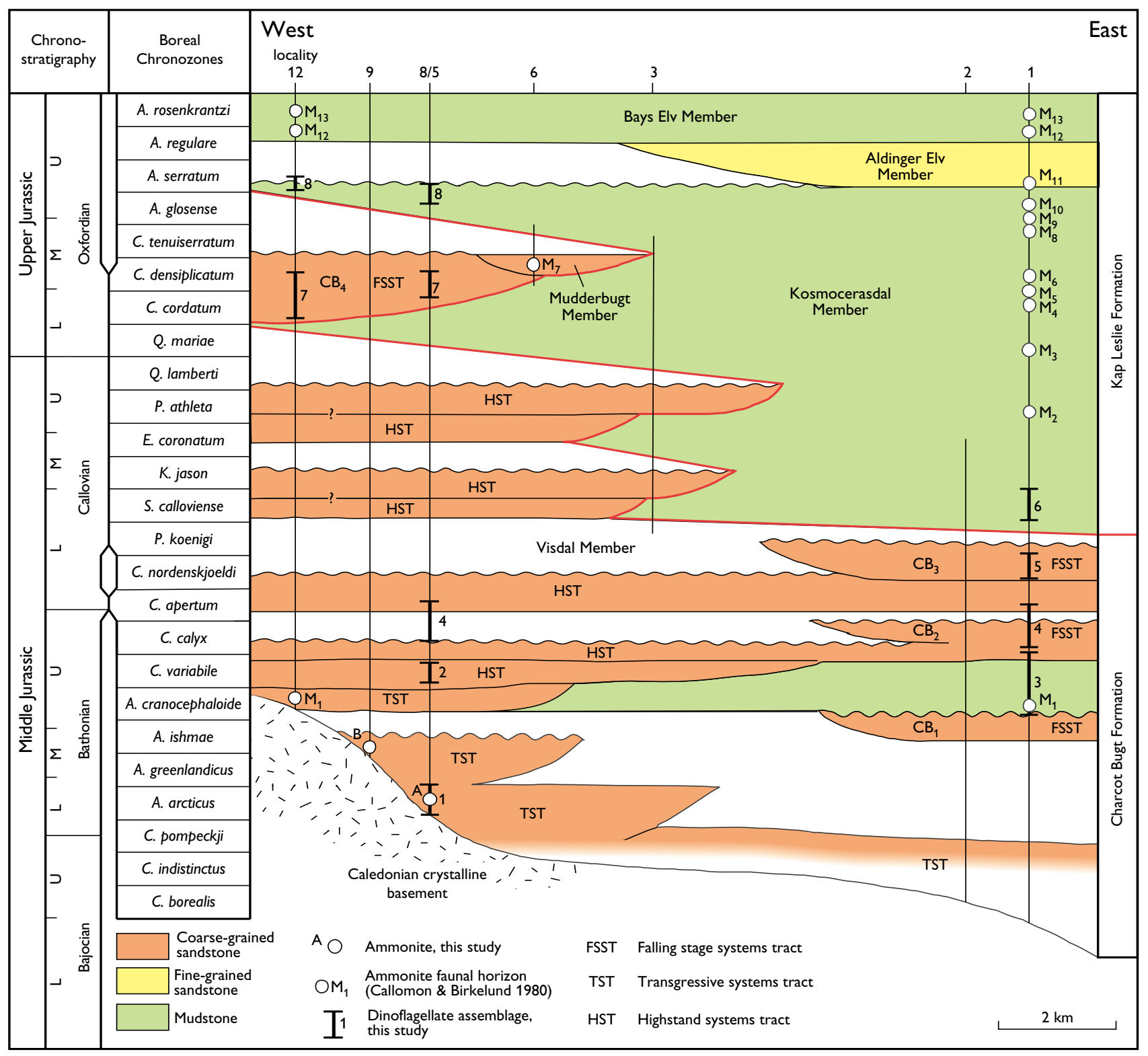

Fig. 4. Lithostratigraphy and chronostratigraphy of the Charcot Bugt Formation and lower Kap Leslie Formation; the boundary between these two formations is emphasised by a red line. The formations are interpreted to form genetically-linked depositional systems with the Kosmocerasdal Member as the fine-grained offshore correlative of the coarse-grained Charcot Bugt Formation. Note the westwards backstepping of the Charcot Bugt Formation reflecting the overall transgression during the Bathonian - Middle Oxfordian. $\mathbf{C B}_{\mathbf{1}}-\mathbf{C B}_{\mathbf{4}}$, clinoform units within the Charcot Bugt Formation. Ammonite zonation based on Callomon (1993).

\section{Ammonite stratigraphy}

Correlation of the Boreal lower Middle Jurassic ammonite zonation of East Greenland with the Tethyan European ammonite zonation is hindered by faunal provincialism; the faunal horizons in the basal Charcot Bugt Formation are referred to the Boreal zonation (Callomon 1959,
1972, 1993, 2003, this volume). In this study, two ammonite zones not previously recognised in Milne Land are reported. The oldest of these is the Lower Bathonian $A$. arcticus Chronozone, which is represented by a single specimen of Arctocephalites cf. arcticus (Whitfield) found in the basal beds of the Charcot Bugt Formation at Visdal (Figs 1, 4, locality 8). This 
specimen dates the timing of inundation of the Milne Land area to the Early Bathonian. However, unfossiliferous sediments exposed in the eastern part of Milne Land (Fig. 1, localities 1,2) are probably even older, given the progressive westwards onlap onto the easterly dipping crystalline basement surface. The second ammonite zone not previously recognised is the Middle Bathonian A. ishmae Chronozone which is represented by a specimen of Arcticoceras harlandi (Rawson) found between localities 8 and 9 (Figs 1, 4).

The Upper Bathonian A. cranocephaloide Chronozone is represented by specimens of Arcticoceras/ Cadoceras sp.nov.? aff. variabile (Spath) and Kepplerites tychonis (Ravn) from a conglomerate immediately above the contact to the crystalline basement surface at locality 14 (Fig. 1; Håkansson et al. 1971; Callomon \& Birkelund 1980, fauna $\mathrm{M}_{1}$ ). The A. cranocephaloide Chronozone is probably also represented at locality 1 in the western part of the area, c. $130 \mathrm{~m}$ above the basement (Fig. 1; Callomon \& Birkelund 1980, fig. 2).

At Visdal, a succession of medium-grained unfossiliferous sandstones, approximately $60 \mathrm{~m}$ thick, overlies the bed containing fauna $\mathrm{M}_{1}$ (A. cranocephaloide Chronozone); the C.variabile, C. calyx, C. apertum, C. nordenskjoeldi and P. koenigi Chronozones have not been documented by ammonites in Milne Land. In the uppermost part of the Charcot Bugt Formation in Visdal (the Mudderbugt Member), specimens of Perisphinctes (Arisphinctes) cf. or aff. maximum (Young \& Bird) indicate the Middle Oxfordian C. densiplicatum Chronozone, probably the C. maltonense Subzone (Callomon 1961; Callomon \& Birkelund 1980, fauna $\mathrm{M}_{7}$ ).

A complete Middle-Upper Jurassic ammonite succession from the Upper Callovian P. athleta Chronozone to the Middle Volgian L. groenlandicus Chronozone is present in the Kap Leslie Formation at locality 1 and eastwards (Fig. 1), and forms a standard for the Boreal ammonite zonation (Spath 1935, 1936; Callomon \& Birkelund 1980; Birkelund et al. 1984). The Kosmocerasdal Member yields ammonites of the Upper Callovian P. atbleta Chronozone (faunal horizon $\mathrm{M}_{2}$ of Callomon \& Birkelund 1980) from concretionary levels $12 \mathrm{~m}$ and $30 \mathrm{~m}$ above the top of the Charcot Bugt Formation (Figs 1, 4, locality 1). Ammonites representing the Lower Oxfordian Q. mariae and C. cordatum Chronozones and the Middle Oxfordian $C$. densiplicatum Chronozone are found higher in the succession (faunal horizons $\mathrm{M}_{3}-\mathrm{M}_{6}$ of Callomon \& Birkelund 1980). The Middle Oxfordian C. tenuiserratum and the Upper Oxfordian A. glosense Chronozones are represented in the upper part of the Kosmocerasdal Member (faunal horizons $\mathrm{M}_{8}-\mathrm{M}_{10}$ of Callomon \& Birkelund 1980).

The Aldinger Elv Member contains fauna $\mathrm{M}_{11}$ of the Upper Oxfordian $A$. glosense and $A$. serratum Chronozones (Birkelund \& Callomon 1980). The base of the Bays Elv Member corresponds to the Upper Oxfordian A. regulare Chronozone and appears to be isochronous throughout Milne Land (Fig. 4; Callomon \& Birkelund 1980; Piasecki 1980).

\section{Dinoflagellate cyst stratigraphy}

Ongoing studies of the Jurassic dinoflagellate cyst stratigraphy in East Greenland show that the stratigraphic distribution of most species deviates significantly from the distribution reported from the North Sea region. The Jurassic sediments of East Greenland are therefore dated within the framework of the local dinoflagellate stratigraphy (Piasecki 1980; S. Piasecki and P. Milner, unpublished data) that is correlated with the Boreal ammonite zonation (Fig. 5).

The mostly unfossiliferous coarse-grained sediments of the Charcot Bugt Formation have always represented a stratigraphic problem and have hitherto only yielded four horizons with ammonites. However, dinoflagellate cyst assemblages have been found to occur in thin muddy beds and have greatly improved the subdivision and correlation within the formation. In the partly contemporaneous, offshore marine Kap Leslie Formation, ammonites and dinoflagellate cysts occur more abundantly. The dinoflagellate cyst microflora is of Bathonian age in the lower part of Charcot Bugt Formation and of Callovian and Oxfordian age in the upper part of the formation and in the Kap Leslie Formation. The microflora is subdivided into eight stratigraphic assemblages (Appendix 1). Assemblages $1-5$ and 7 are present in fine-grained beds in the Charcot Bugt Formation whereas assemblages 6 and 8 are from silty mudstones of the Kap Leslie Formation (Fig. 4).

The dinoflagellate cyst zonation shows that the basal unit of the Kap Leslie Formation, the Kosmocerasdal Member in Kosmocerasdal to the east, is of Early Callovian S. calloviense Chron age (assemblage 6). This is considerably older than hitherto believed on the basis of ammonites of Late Callovian age found $12 \mathrm{~m}$ above the formation boundary (Callomon \& Birkelund 1980). Samples from fine-grained levels in the upper part of the Charcot Bugt Formation show the presence of sediments of the Lower Oxfordian C. cordatum, and the Middle Oxfordian C. densiplicatum Chronozones (assem- 


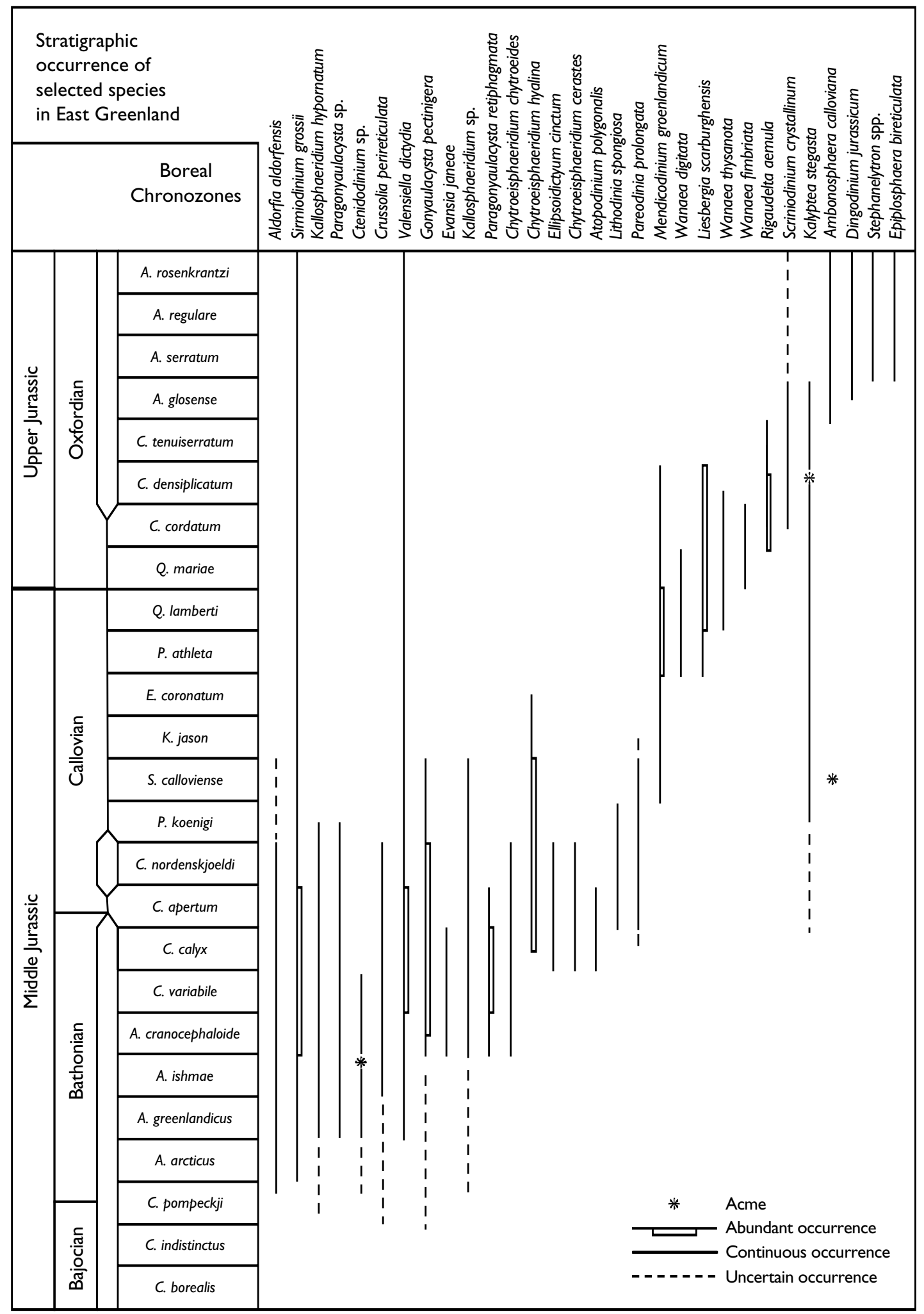

Fig. 5. Stratigraphic occurrence of selected dinoflagellate cyst species in Jameson Land, used for dating the assemblages in Milne Land. 


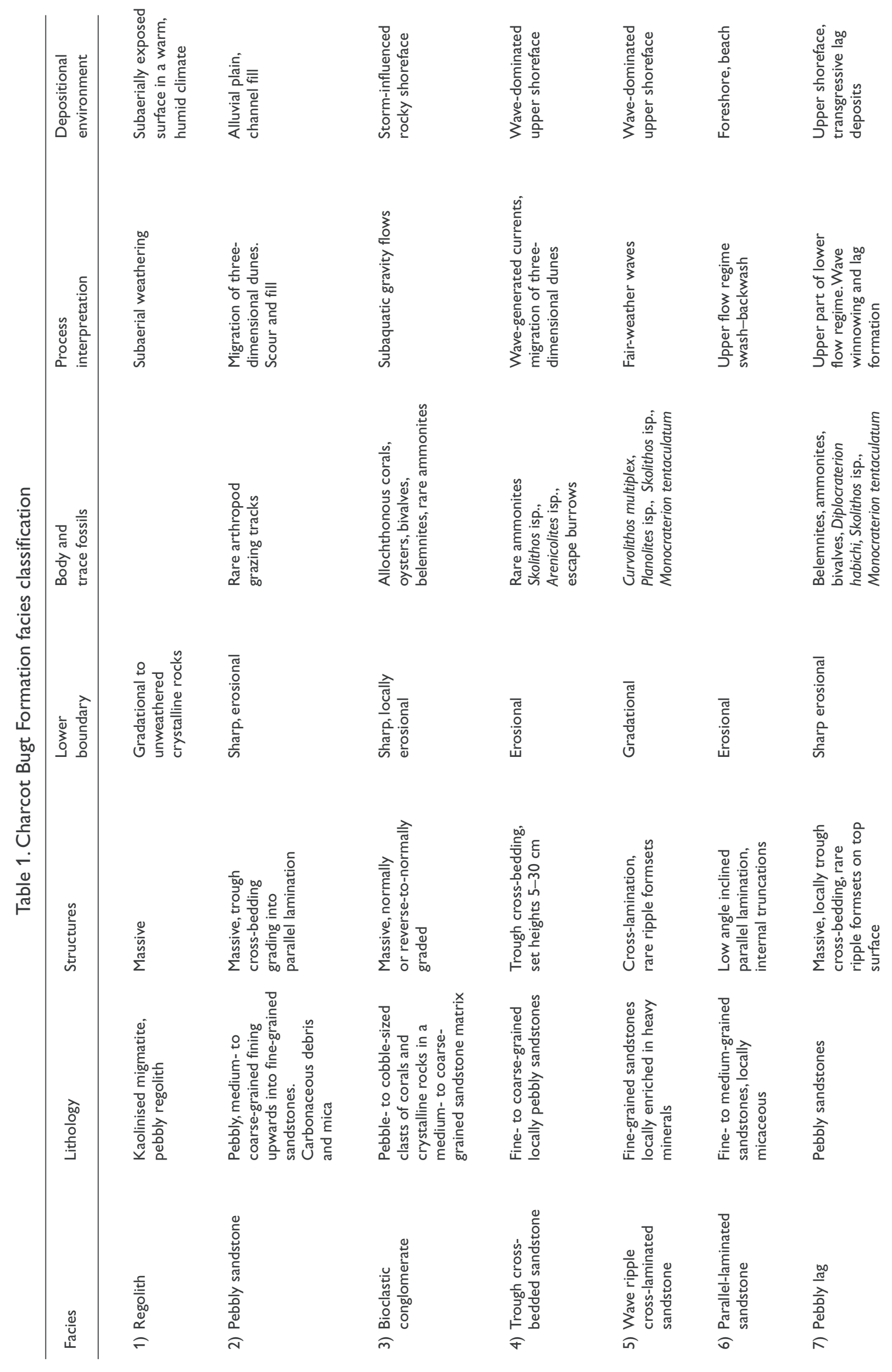




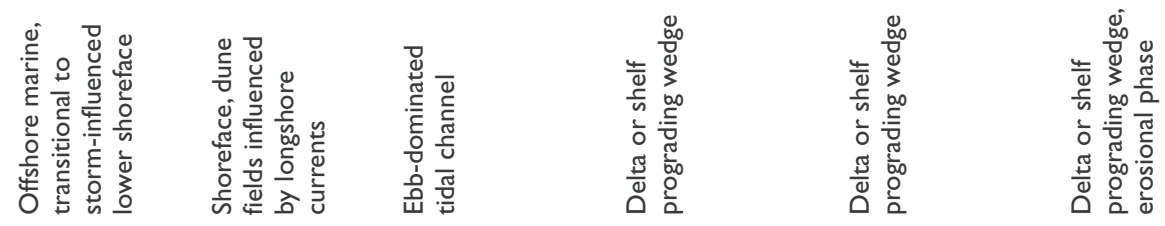

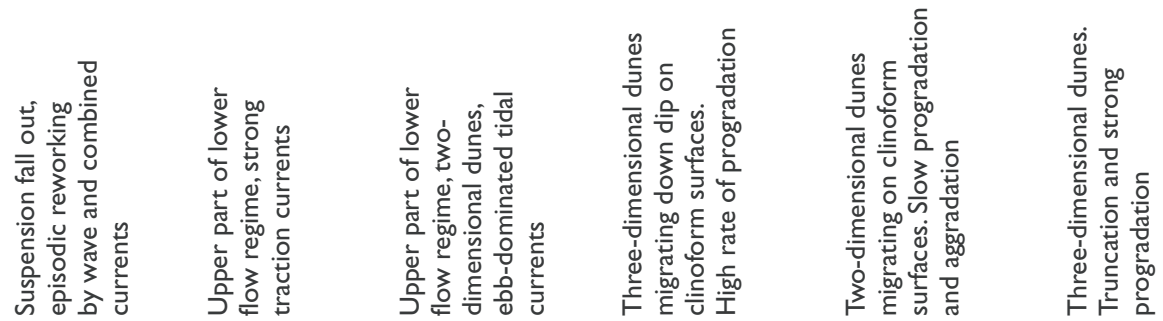

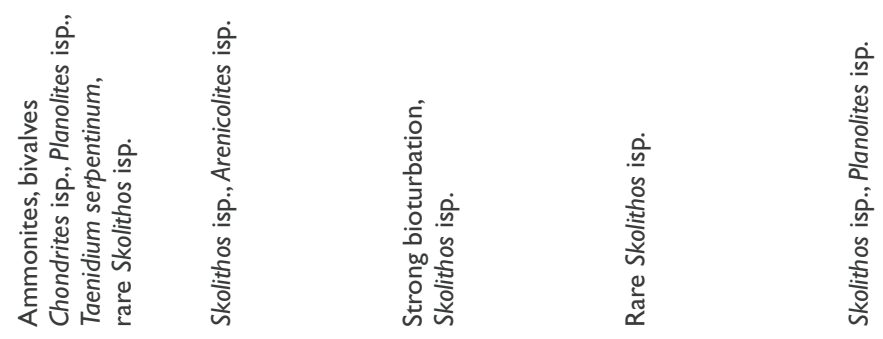
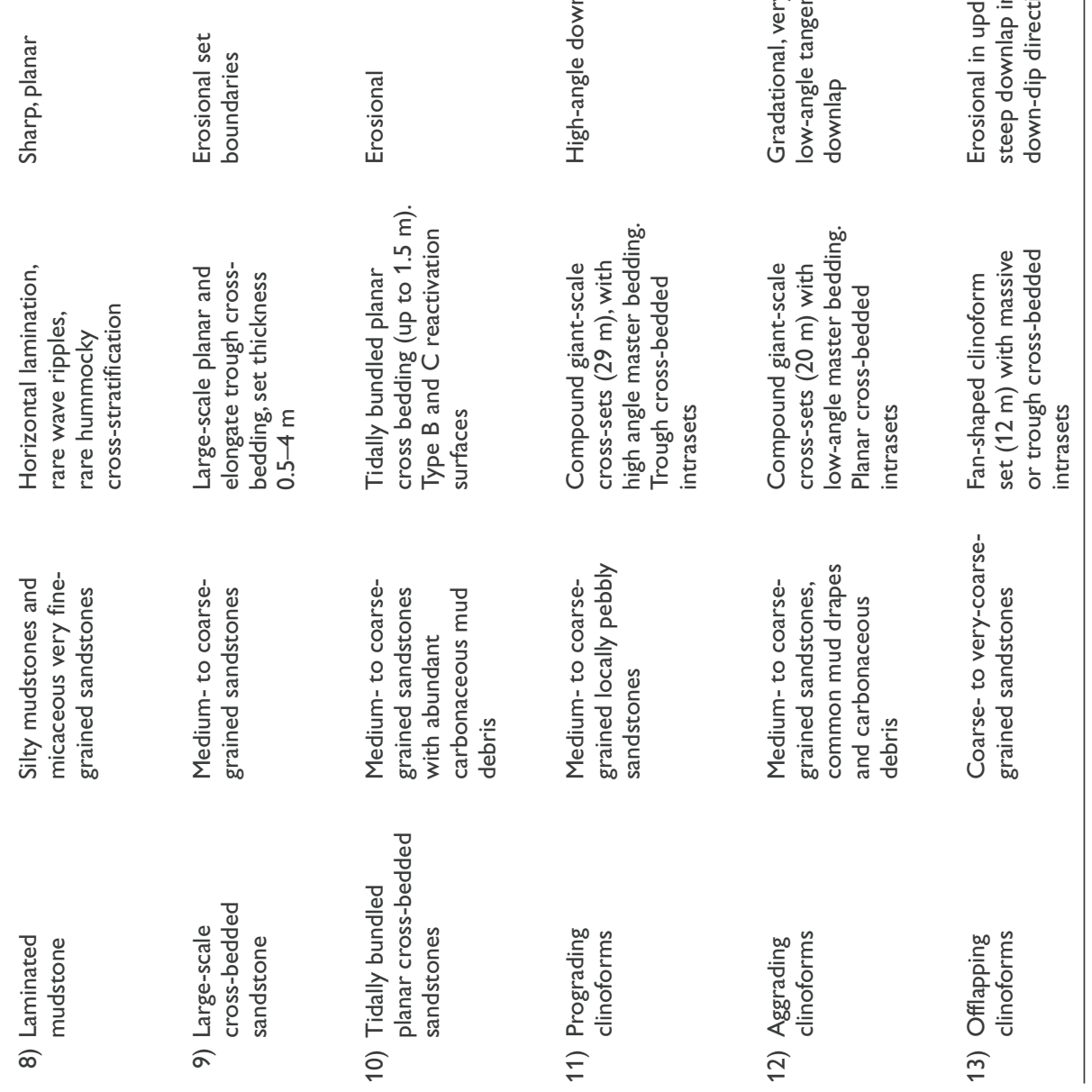


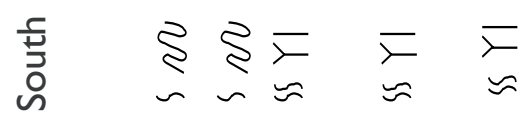
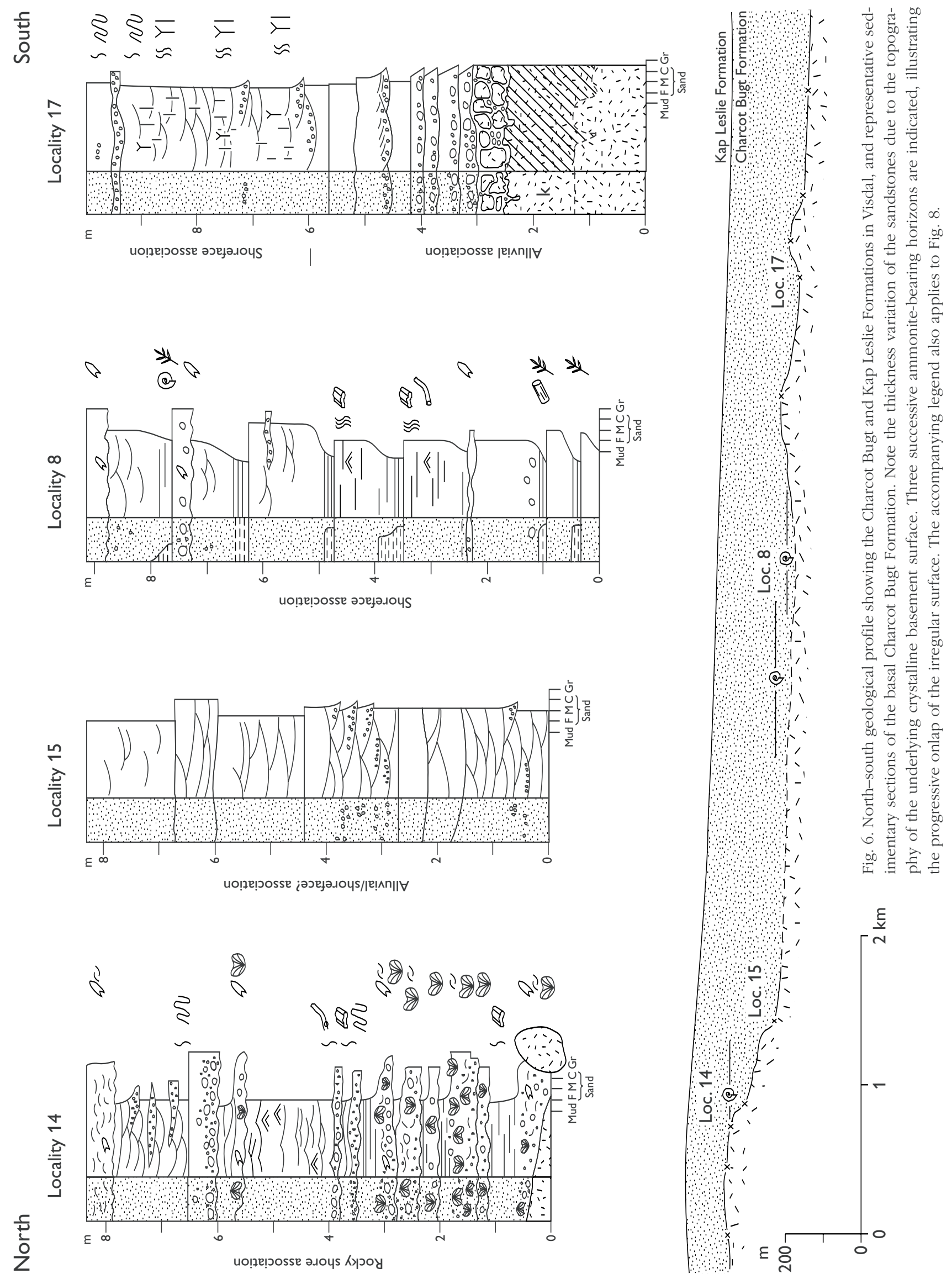


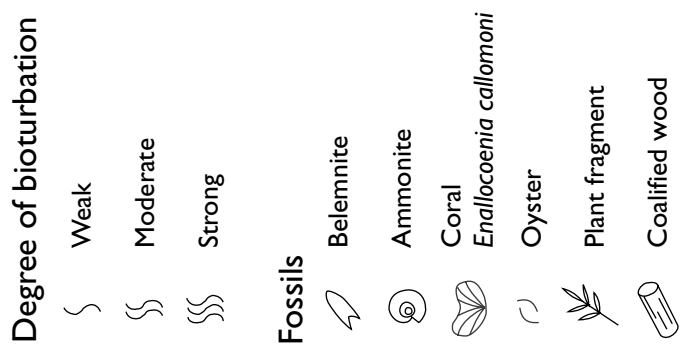

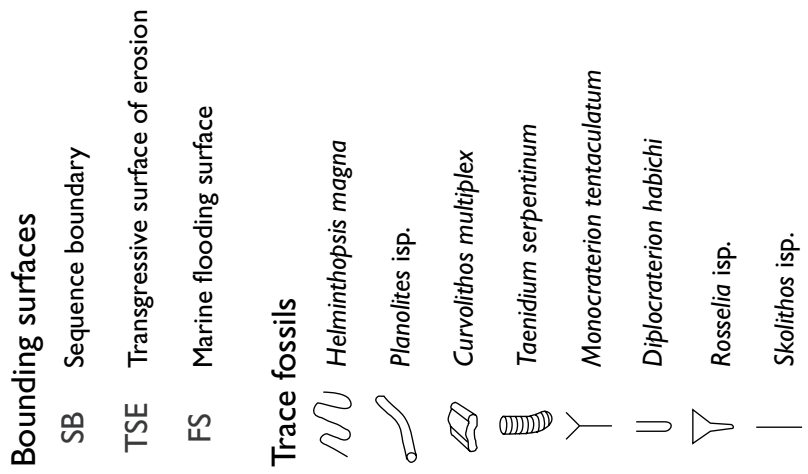
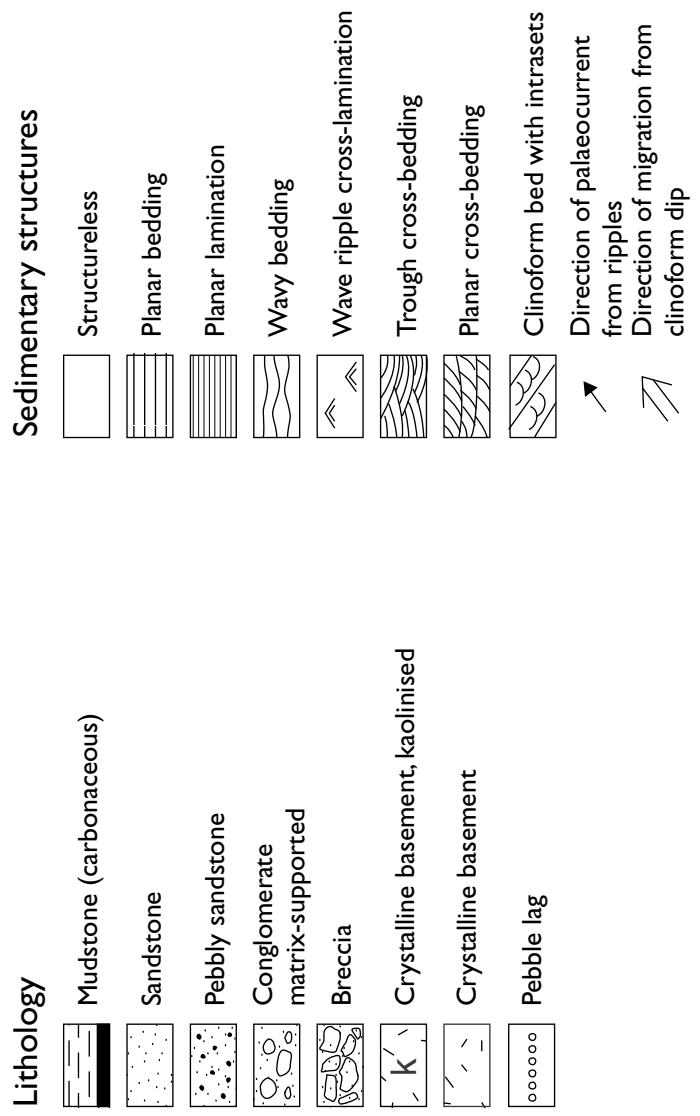

blage 7) and thus preclude the existence of a major hiatus between the Visdal and Mudderbugt Members, contrary to the interpretation of Callomon \& Birkelund (1980). The dinoflagellate cyst samples from the Kap Leslie Formation in Visdal to the west indicate the presence of the Upper Oxfordian A. glosense and A. serratum Chronozones (assemblage 8) in the mudstones directly above the Charcot Bugt Formation. The palynological data allow correlation of the upper sandstone units with the offshore marine mudstones, which were previously interpreted to overlie the sandstones with a major hiatus (Callomon \& Birkelund 1980). The new data thus indicate a genetic relationship between the Charcot Bugt Formation and the Kosmocerasdal Member of the Kap Leslie Formation (Fig. 4).

\section{Sedimentology}

Thirteen facies are recognised in the Charcot Bugt Formation (Table 1). They are grouped into the alluvial, rocky shoreline, shoreface, prograding wedge, and offshore facies associations, each characterised by their constituent facies, geometrical arrangement of facies types, nature of bounding surfaces, and overall geometry. The facies associations are interpreted in terms of depositional environments and correspond to depositional systems.

\section{Alluvial facies association (facies 1,2)}

The alluvial facies association is restricted to the basal part of the formation, mainly situated in local topographical basement lows (Fig. 6). The association consists of facies 1 (kaolinised migmatite/regolith) overlain by facies 2 (cross-bedded sandstones) showing an overall fining-upwards trend (Table 1).

\section{Description}

The crystalline basement consists of gneissic migmatite and banded coarse-grained granitic migmatite (BucherNurminen 1979; Henriksen \& Higgins 1988). The rocks are progressively weathered upwards towards the contact with the sediments forming an up to $2.5 \mathrm{~m}$ thick regolith (facies 1; Fig. 6, locality 17). The overlying massive sandstones (facies 2) are coarse-grained, locally pebbly, arkoses with lenses of subrounded quartz pebbles, lithic fragments and kaolinised and fresh feldspar. 
Clasts are rounded to well-rounded, spherical and subdiscoidal pebbles of vein quartz, up to $9 \mathrm{~cm}$ in diameter. The sandstones grade up into cosets of trough cross-bedded, medium- to coarse-grained sandstone, with pebbly lenses and scattered pebbles (Fig. 6, localities 15, 17). Foreset azimuth orientations indicate transport directions towards the south-east. Even, parallel laminated well-sorted, very fine- to fine-grained sandstones form the top of the fining-upwards successions. The lamination is defined by abundant flakes of mica and carbonaceous detritus. Bioturbation is restricted to scattered meandering grazing traces (pascichnia) preserved as shallow epireliefs on bedding planes in the thin-bedded upper part of fining-upwards successions.

\section{Interpretation}

Weathering of the crystalline basement surface and formation of the regolith took place during a period of subaerial exposure. The dominance of kaolinite in the weathering profile may suggest a warm, humid climate (Curtis 1990; Retallack 1990).

The overlying poorly sorted pebbly sandstones, containing reworked subangular lithic fragments, kaolinitic feldspars and quartz, are interpreted to have been deposited in an alluvial environment where clasts were transported only relatively short distances before deposition. The dominance of trough cross-sets and the unimodal palaeocurrent direction perpendicular to the reconstructed palaeo-gradient further support this interpretation (Fig. 3; Larsen 1995). The sandstones were deposited by three-dimensional dunes in the upper lower flow regime, or represent the fill of shallow scours, and probably formed in shallow channels dominated by bedload transport (Miall 1977, 1978; Rust 1978, Kleinspehn et al. 1984).

Deposits of the alluvial facies association may have formed a more extensive and continuous cover of the basement surface prior to the Middle Jurassic transgression, during which the main part was reworked and redistributed by marine currents or waves. The variation in thickness of the regolith may reflect primary variation in depth of weathering or later erosion.

\section{Rocky shore association (facies 3-6)}

The rocky shore association consists of bioclastic conglomerates (facies 3), trough cross-bedded sandstones (facies 4), wave ripple cross-laminated sandstones (facies
5) and parallel-laminated sandstones (facies 6; Table 1). The facies occur in random successions with abundant internal scour and erosion surfaces. The association is present in the immediate vicinity of crystalline basement highs (Fig. 6, locality 14).

\section{Description}

The association onlaps the steeply rising crystalline basement surface in the northern part of Visdal (Fig. 6). In contrast to the low relief basement surface in the southern part of Visdal (see above), the crystalline rocks at the onlap surface are generally fresh. Neptunian dykes occur where small fractures in the surface are filled with coarse-grained sandstones and well-rounded crystalline pebbles or fragmented oyster shells (Fig. 7A). Despite a thorough search, no in situ epifauna was found on the basement surface. A well-rounded gneiss boulder more than $1 \mathrm{~m}$ in diameter, surrounded by coarse-grained sandstones, occurs in the basal part of the succession near the basement surface at locality 14 (Fig. 6).

The conglomerates (facies 3) are matrix-supported with pebble- to cobble-sized clasts in a coarse-grained sandy matrix. Clasts may be polymict, comprising quartz pebbles, lithic fragments, belemnites, fragments of corals and oyster shells (Fig. 7B) or they may be composed exclusively of fragments of the coral Enallocoenia callomoni (Beauvais) (Fig. 7C). The corals have been affected by bioerosion and Gastrochaenolites borings, representing resting nests of bivalves such as Lithophaga or Gastrochaena, are common (Fig. 7D; Frey \& Seilacher 1980). The conglomerates form tabular beds, up to $50 \mathrm{~cm}$ thick, with a sharp, locally erosional base and inverse-to-normal or normal grading. Well-sorted fine-grained sandstone caps, up to $c .30 \mathrm{~cm}$ thick, show parallel lamination. Bedding surfaces locally show horizontal traces of Taenidium serpentinum and Helminthopsis magna. The conglomerates are associated with fine- to coarse-grained sandstones that are pebbly in places (facies 4). The sandstones are trough cross-bedded with set thickness between 5 and $30 \mathrm{~cm}$. High angle scours may be partly filled with pebbly sandstones, and clast-supported conglomerate sheets occur interbedded with the cross-sets (Fig. 7E). Foreset orientations in the trough cross-beds indicate dominant transport towards the south.

The coarse-grained facies are interbedded with wellsorted fine- to medium-grained wave ripple cross-laminated sandstones (facies 5), showing intense burrowing 

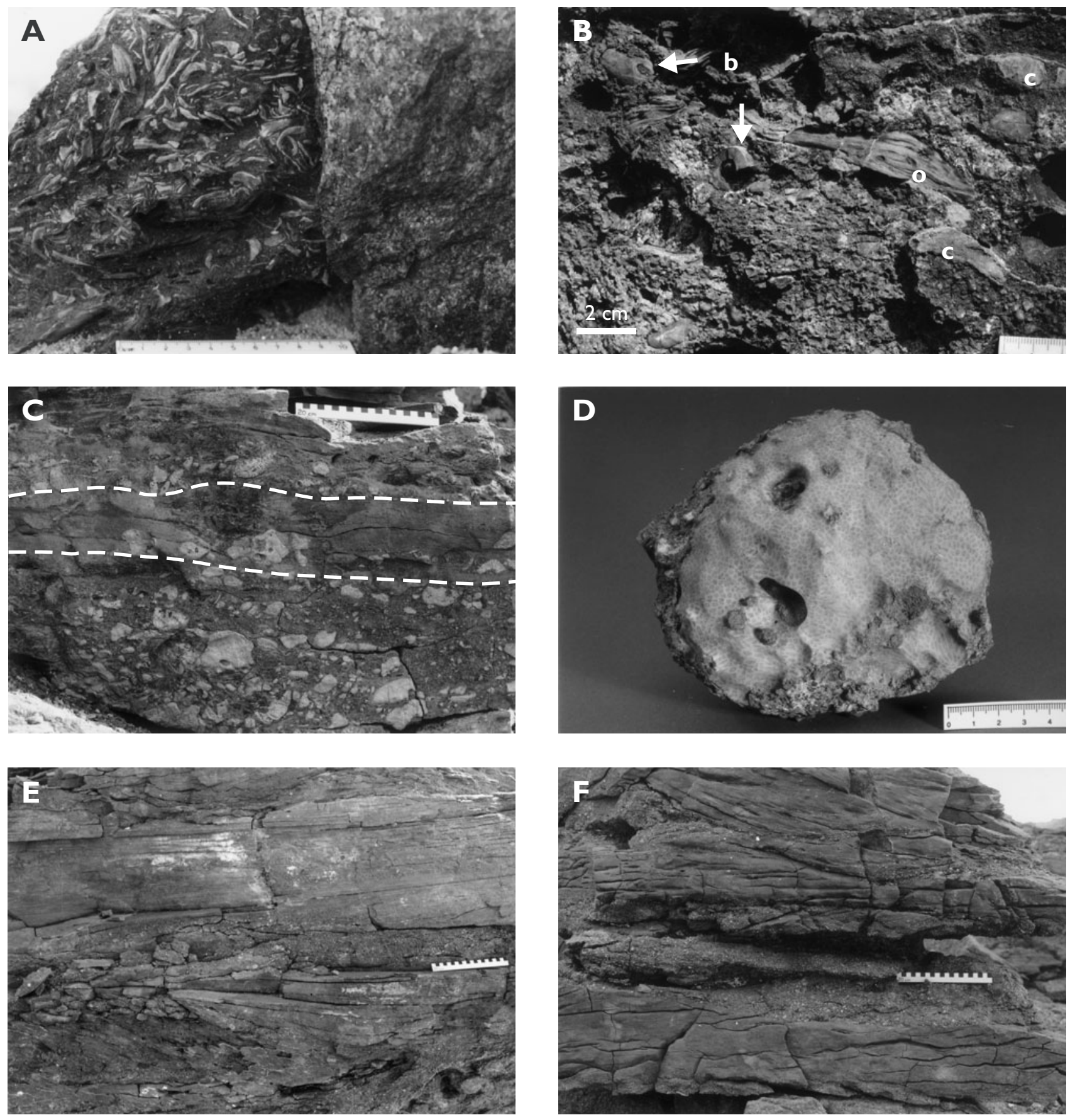

Fig. 7. Examples of sedimentary facies and faunas of the rocky shoreline association. Scale in centimetres. A: Subvertical contact between a coquina and unweathered crystalline basement. The shelly debris was deposited in a fracture in the basement surface forming a neptunian dyke. B: Polymict siliciclastic and bioclastic conglomerate with lithic fragments, quartz pebbles, fragmented corals (c), oysters (o), and worn well-rounded belemnites (b). C: Marine matrix-supported conglomerates with coral clasts. Photograph shows vertical stacking of three graded beds. Bed boundaries indicated by dashed lines. D: Compact hemispherical colony of the hermatypic coral Enallocoenia callomoni Beauvais recovered from a conglomerate. The coral shows sand-filled Gastrochaenolites borings probably representing nests of boring bivalves. E: Pebbly sandstones filling a shallow scour interpreted as a rip-channel fill (lower part, under scale). Note the gradual upwards decrease in the dip of the foresets and concomitant decrease in grain size. The rip-channel fill is overlain by parallel-laminated sandstone (above scale). F: Wave-rippled sandstones truncated by pebbly trough cross-bedded sandstones. Note the abrupt changes in grain size and the abundant erosional surfaces. 
by Curvolithos multiplex, and parallel-laminated wellsorted fine- to medium-grained sandstones, locally rich in mica (facies 6). Bed thicknesses reach $30 \mathrm{~cm}$, but may be reduced due to truncation by pebble-filled scours (facies 4; Fig. 7F). The parallel lamination of facies 6 is defined by coarse sand grains or fine quartz pebbles and small coralline fragments. The lamination dips a few degrees and shows low-angle internal truncations.

\section{Interpretation}

The generally poor sorting of the pebbly sandstones and the composition of the conglomerates point towards mixing of marine and terrestial sediments, suggesting marine reworking of alluvial sediments. Textural sorting and marked grain-size segregation between individual sets are characteristic of sediments deposited in the ambient energy regime on a wave-dominated upper shoreface (Dupré et al. 1980; Clifton 1981; Nemec \& Steel 1984; Leithold \& Bourgeois 1984). The trough cross-stratified pebbly sandstones were deposited by strong unidirectional currents that may have been generated by storm surges either along the coast or in rip channels. The matrix-supported graded conglomerates contain dispersed floating clasts, a fabric that invites comparison with debris flow deposits. The out-sized clasts, however, consist primarily of corals, which may have shown a different hydrodynamic behaviour from siliciclastic material of equal size. The floating clasts therefore are not unequivocal criteria with respect to the depositional process. However, the overall inverse-to-normal grading present in some beds and the lack of traction current generated structures support the interpretation that they represent high density gravity flow deposits (Lowe 1979, 1982). The cross-laminated fine-grained sandstones (facies 5) that form a cap on some of the conglomerate beds are interpreted to represent reworking by fair-weather waves. The shallow water depth in front of the rocky shoreline is reflected by the parallellaminated sandstones formed by high-energy swashbackwash on the foreshore or by shoaling waves on the upper shoreface (Clifton 1969).

The well-rounded gneiss boulder embedded in marine sediments indicates exposure to wave processes probably on a high-energy beach before final burial (Dott 1974; Surlyk \& Christensen 1974). It may have originated from wave erosion of the rocky coastline removing a joint-controlled weathering crust leaving the rounded boulder in place or it may have rolled or slid into the site of deposition.
The rocky shore association is bounded by the crystalline basement in a landwards direction. The association may be characterised as amalgamated marine lag deposits formed by progressive wave erosion of the basement and alluvial deposits and by winnowing of shoreface and foreshore deposits in a high energy rocky shoreline environment.

\section{Shoreface association (facies 4, 5, 7-9)}

Stacked units of the shoreface association form the bulk of the Charcot Bugt Formation. Each unit shows a basal erosional surface overlain by a coarse-grained lag deposit (facies 7). The lag is sharply overlain by silty mudstones forming the base of an overall coarsening-upwards succession (facies 8, 4, 5, 9), up to $22 \mathrm{~m}$ thick (Fig. 8).

\section{Description}

The basal lag deposits reach a maximum thickness of $1 \mathrm{~m}$ and are composed of coarse- to very coarse-grained quartzitic sandstone with concentrations of worn belemnites and ammonites. The lags are intensely burrowed by Skolithos isp. and Diplocraterion habichi (facies 7; Fig. 8). The upper bedding surfaces are planar or locally reworked into large-scale wave ripples.

The lag deposits are abruptly overlain by laminated mudstones (facies 8) that form the lower part of the coarsening-upwards successions. The siltstones grade upwards into well-sorted mica-rich, very fine- to fine-grained sandstones, showing wave ripple cross-lamination and symmetrical ripples on bedding planes (facies 5). The sandstones are strongly bioturbated and show well-preserved Curvolithos multiplex and Planolites isp. The fine-grained sandstones are overlain by cosets, 6-10 $\mathrm{m}$ thick, of trough cross-bedded, medium-grained sandstones (facies 4). Individual sets are medium-scale trough cross-beds with set thickness between 5 and $25 \mathrm{~cm}$ and low-angle foresets. The Mudderbugt Member consists solely of coarse-grained sandstones of facies 4.

In Visdal, the uppermost of the shoreface units contains cosets of very large-scale, planar and trough cross-bedded, medium- to coarse-grained sandstones (facies 9; Figs 8, 9). The cosets have a sheet-like geometry and are bounded by erosional planar surfaces. They are up to $9 \mathrm{~m}$ thick; individual sets are up to $4 \mathrm{~m}$ thick, with $0.5-1.5 \mathrm{~m}$ being most common. The set boundaries form more than $10 \mathrm{~m}$ wide troughs, with erosional boundaries to underlying sets (Fig. 9). Foresets 

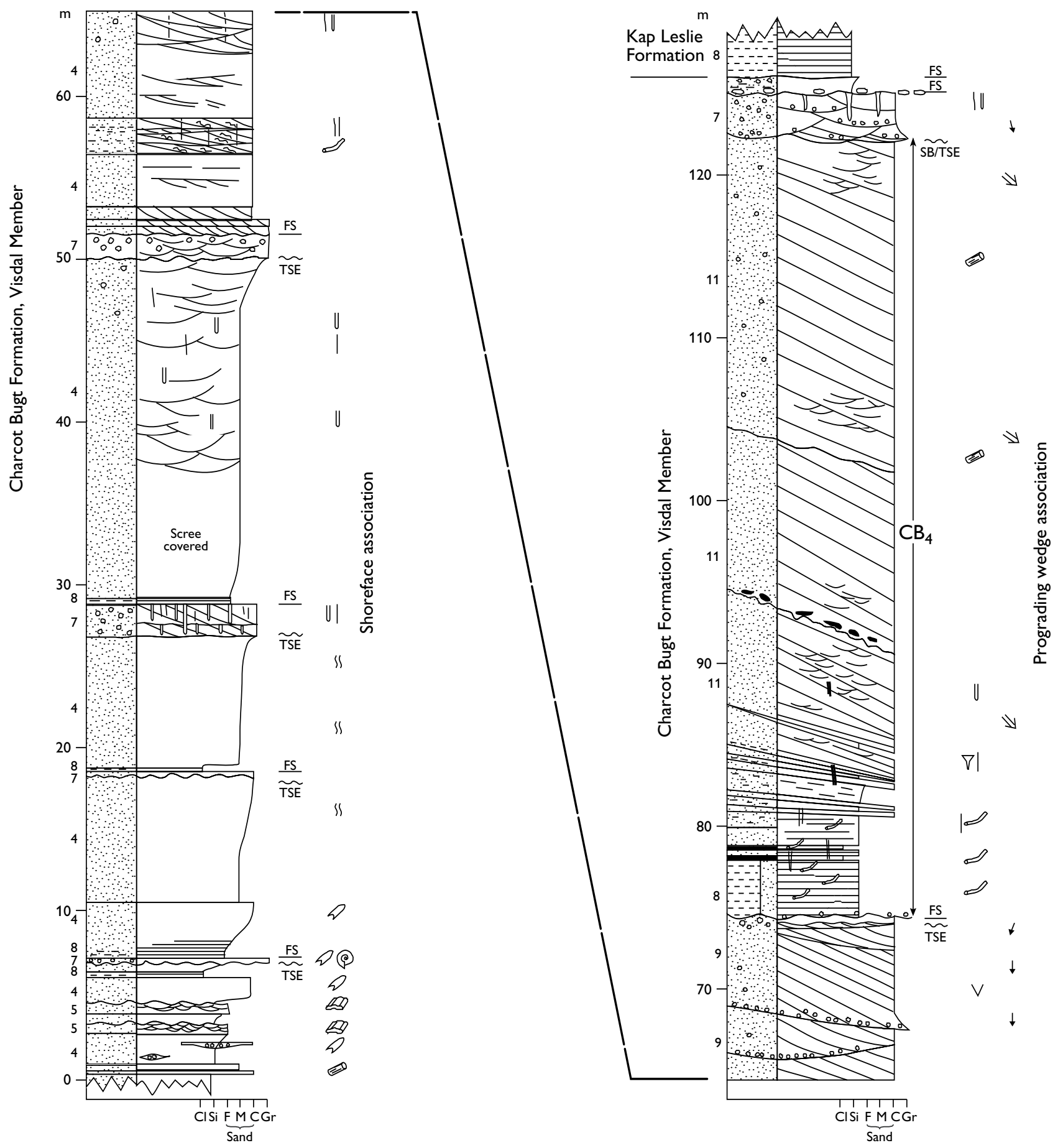

Fig. 8. Sedimentological section measured through the upper part of the Charcot Bugt Formation showing stacked coarsening-upwards shoreface successions overlain by clinoform unit $\mathrm{CB}_{4}$. The small numbers indicate facies, as described in the text. For legend, see Fig. 6.

are dominantly tangential or more rarely sigmoidal. Individual cross-sets show inversely or, rarely, normally graded simple avalanche foresets up to $40 \mathrm{~cm}$ thick. Locally, the foresets are compound showing internal lowangle trough cross-bedding. The large-scale foresets dip up to $23^{\circ}$ with a consistent dip direction towards the south (mean $196^{\circ}$; Fig. 10). Bioturbation is rare; isolated Arenicolites isp. and Skolithos isp. burrows occur locally. 

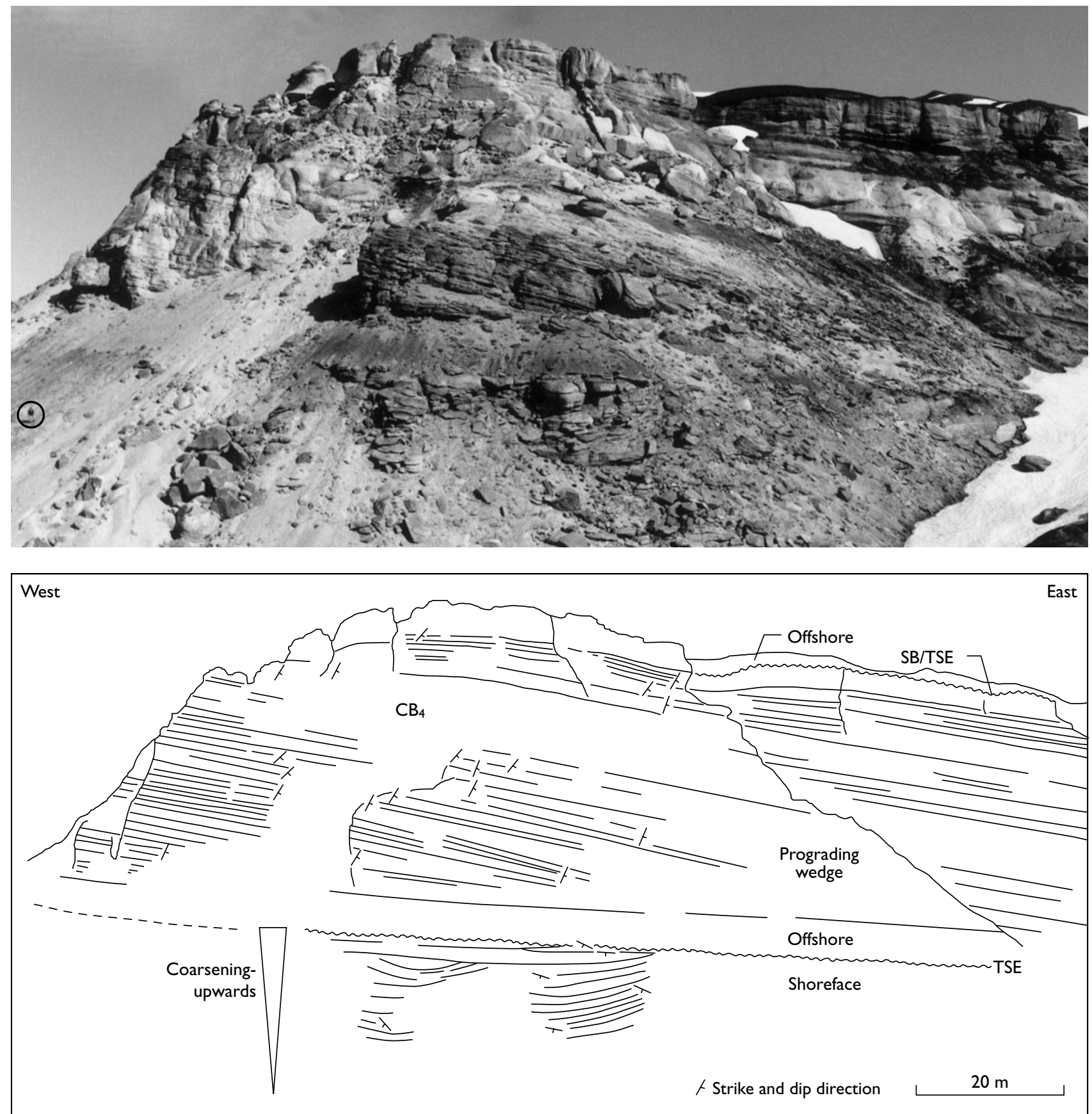

Fig. 9. Prograding clastic wedge $\left(\mathrm{CB}_{4}\right)$ forming the top of the Charcot Bugt Formation at Visdal. The unit is more than $50 \mathrm{~m}$ thick and downlaps onto marine mudstones that themselves succeed a coarsening-upwards shoreface succession lowermost in the photograph. View towards the north-east. The line drawing is based on the photograph and measured vertical sections. Note the steeply dipping clinoforms in the central part of the photograph. Person encircled for scale.

\section{Interpretation}

The lateral continuity of the erosionally-based pebbly sandstones and the presence of marine macrofossils and wave-generated ripples suggest that the lag (facies

7) formed by shoreface ravinement followed by shallow marine winnowing (Swift 1968; Demarest \& Kraft 1987; Nummedal \& Swift 1987). The trace fossils belong 
to the habichi ichnocoenosis (Heinberg \& Birkelund 1984) and are interpreted to indicate shallow marine to intertidal, high energy environments characterised by highly varying sedimentation and erosion rates (Heinberg \& Birkelund 1984; Dam 1990). The overlying finegrained sediments are interpreted as having been deposited from suspension fall-out below storm wave base and the transition thus indicates an abrupt increase in water depth and is designated a marine flooding surface. Although this surface is easily recognised in outcrop, the definition of the facies associations as genetically-related facies implies that the lower boundary of cycles in the shoreface association is placed at the erosional base (marine surface of erosion) of the coarse-grained lag (see Arnott 1995).

The coarsening-upwards part of the successions is interpreted to represent shoreface progradation. The fine-grained strongly bioturbated sandstones indicating slow sedimentation rates and deposition in a low energy environment were deposited on the lower shoreface. The upper shoreface is represented by medium- and coarse-grained trough cross-bedded sandstones (facies 4) deposited by three-dimensional dunes in a highenergy wave-regime. The near-shore shallow marine sand sheets and shoreface environments are characterised by a high degree of reworking (Dupré et al. 1980; Clifton 1981). The high energy, shallow marine environment is also reflected by the trace fossils which are dominated by vertical burrows probably inhabited by suspension feeders.

The interpretation of the very large-scale cross-sets (facies 9) is less straightforward. No unequivocal evidence of wave or tidal action is present and the consistent palaeocurrent direction, indicated by the dip of the very large-scale foresets, suggests unimodal currents. Based on the sedimentary structures alone the sandstones may have been deposited by large sandbars or mouthbars in either fluvial, tidal or shallow marine environments. The association with upper shoreface facies and the presence of marine trace fossils (albeit scarce), however, suggest a tidal to shallow marine depositional environment.

Tidally-driven current systems are often separated into an ebb- and a flood-dominated thalweg, and the lack of tidal structures may therefore not be significant. Berné et al. (1991) described large-scale dunes from recent subtidal environments, that were $0.7-9.4 \mathrm{~m}$ high with common heights between $2-4 \mathrm{~m}$ and formed in water depths between 8 and $23 \mathrm{~m}$. They migrated under the influence of tidal currents. Large-scale dunes may also form on epicontinental platforms by strong geostrophic currents,
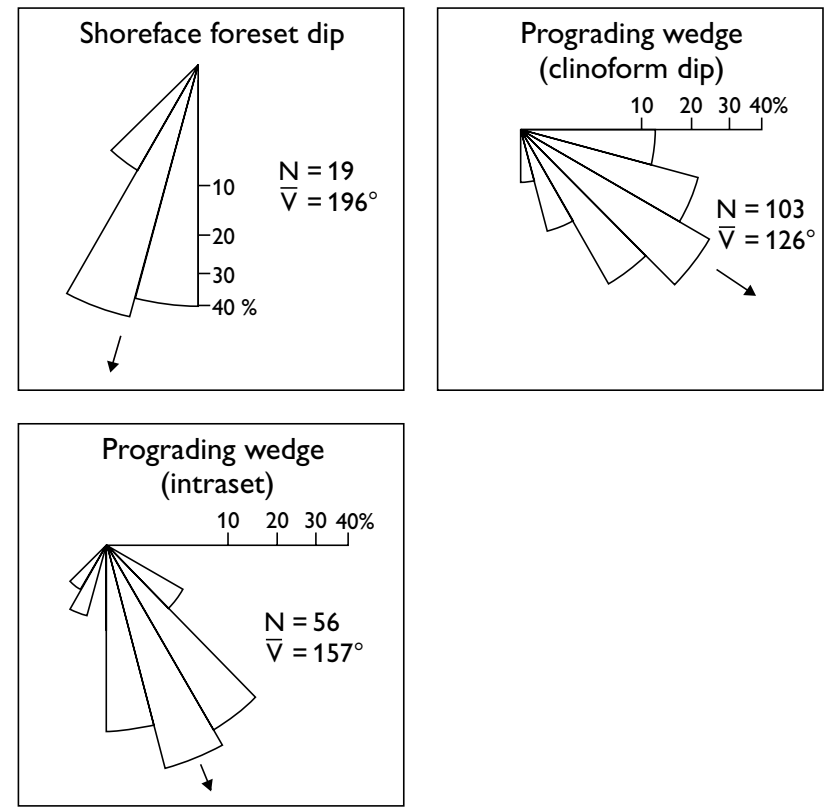

Fig. 10. Equal-area rose plots showing the palaeocurrent direction in the shoreface association (facies 4,9 ) and the clinoform dip direction and intraset palaeocurrent direction in the prograding wedge association (facies 10-13).

occasional storm surges and/or tidal currents (McCave 1971; Flemming 1978; Field et al. 1981).

The sandstones (facies 9) are therefore interpreted to have been deposited by fields of linear or slightly sinuous subtidal dunes on the shoreface. The dune fields migrated southwards under the influence of coast-parallel currents. Surlyk \& Noe-Nygaard (1991) described cross-bedded sandstones of similar scale from the Volgian Raukelv Formation in central Jameson Land, interpreted as having been deposited in dune fields driven by coast-parallel tidal currents.

\section{Prograding wedge association (facies 10-13)}

Four clinoform units $\left(\mathrm{CB}_{1}-\mathrm{CB}_{4}\right)$ characterised by highangle foresets or clinoforms are identified in the Charcot Bugt Formation. The units are bounded by major marine flooding surfaces or erosional surfaces, and consist of facies 10-13 (Table 1). They are of ?Middle-Late Bathonian $\left(\mathrm{CB}_{1}\right)$, Late Bathonian $\left(\mathrm{CB}_{2}\right)$, Callovian $\left(\mathrm{CB}_{3}\right)$ and Early-Middle Oxfordian $\left(\mathrm{CB}_{4}\right)$ age, and form a backstepping succession of sandstone-dominated clinoform units (Fig. 4). 


\section{Description}

The four clinoform units were mapped out in the field and have a bank or wedge-shaped geometry (in the sense of Mitchum et al. 1977). The maximum thicknesses of $\mathrm{CB}_{1}, \mathrm{CB}_{2}, \mathrm{CB}_{3}$ and $\mathrm{CB}_{4}$ are $21 \mathrm{~m}, 19.5 \mathrm{~m}, 31 \mathrm{~m}$ and $50.5 \mathrm{~m}$, respectively. The four units are characterised by steeply dipping clinoforms extending from the top to the base of the unit (facies 11-13; Fig. 9). The clinoforms downlap onto the top of large-scale cross-bedded sandstones (facies 10) or the offshore association. In a basinwards direction, the sandstone-dominated clinoform units pass into, and are overlain by, mudstones of the offshore facies association (the Kosmocerasdal Member).

The clinoforms are tangential or locally sigmoid with an inclination of $5-20^{\circ}$ towards the south-east, although the steepest middle part of the clinoforms may locally reach $24^{\circ}$ (Fig. 9). Clinoforms are asymptotic towards the lower boundary where they merge into a carbonaceous fine-grained clinoform toe. The sigmoidal clinoforms gradually merge upwards into a horizontally bedded, wave-influenced top, whereas the tangential oblique clinoforms are erosionally truncated at the top. The clinoforms are grouped into progradational, aggradational and offlapping clinoform sets (Sydow \& Roberts 1994), according to the geometry of the clinoform sur- faces (Fig. 11). The clinoforms show intrasets of planar cross-strata or cosets of trough cross-strata that are characteristic of the different types of clinoform sets (facies 11-13; Table 1). The clinoform sets are bounded by erosional surfaces of local extent and/or their correlative surfaces

Progradational clinoform sets (facies 11) consist of steeply dipping $\left(15-24^{\circ}\right)$ clinoforms showing low-angle trough cross-bedded intrasets with set thicknesses up to $8 \mathrm{~cm}$. The facies consists mainly of well-sorted coarsegrained sandstone with a low content of carbonaceous debris. Bioturbation is weak.

Aggradational clinoform sets (facies 12) are sigmoidal or tangential with planar cross-bedded intrasets up to $1.4 \mathrm{~m}$ thick. Clinoforms dip $5-14^{\circ}$ and consist of wellsorted fine- to medium-grained, locally coarse-grained sandstones with abundant carbonaceous debris. Bioturbation is moderate to strong.

Offlapping clinoform sets (facies 13) are entirely composed of trough cross-bedded coarse-grained sandstones, forming cosets up to $12 \mathrm{~m}$ thick (Fig. 11). Bioturbation is absent except for Diplocraterion habichi extending downwards from the upper clinoform set boundary. Offlapping clinoform sets are typically found in the upper part of clinoform units and represent the final progradation of the clastic wedge. They show a downstepping (offlapping) geometric arrangement in

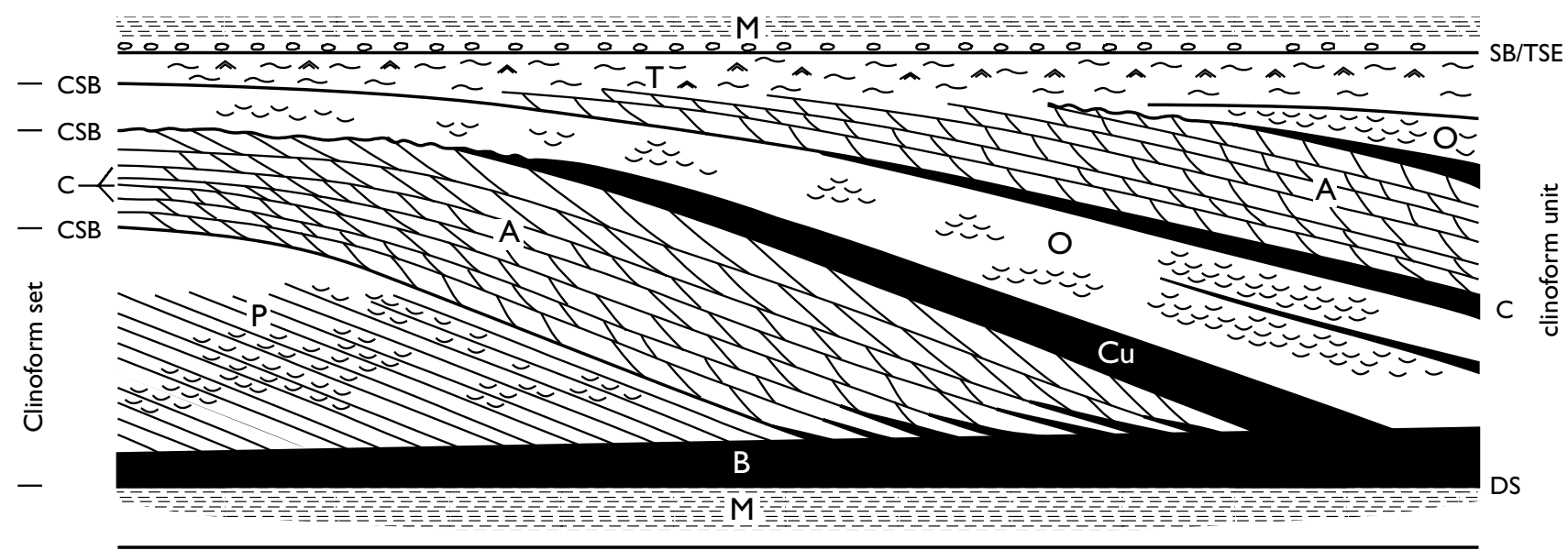

\begin{tabular}{clllll}
\hline DS & Downlap surface & P & Prograding clinoform set & Cu Condensed unit \\
SB/TSE & Coalesced sequence boundary and & A & Aggrading clinoform set & B & Bottomset \\
& transgressive surface of erosion & O Offlapping clinoform set & T & Topset \\
CSB & Clinoform set boundary & M Offshore mudstones & & \\
C & Clinoform surface & & &
\end{tabular}

Fig. 11. Generalised section (scale arbitrary) through a clinoform unit showing the bounding surfaces, structures and geometric characteristics of the clinoform sets. Three types of clinoform sets are described based on the geometry and internal structures. They comprise: prograding (P) (facies 11), aggrading (A) (facies 12) and offlapping (O) (facies 13). The clinoform sets are bounded by erosional surfaces and/or fine-grained condensed units. 
the direction of migration. Up-dip, the offlapping clinoforms may be traced into a strongly erosional surface.

\section{Clinoform unit $\mathrm{CB}_{1}$}

$\mathrm{CB}_{1}$ is exposed in steep cliff faces at Kosmocerasdal and Parat Kløft (Fig.1, localities 1, 2). Minimum areal extent of the clinoform unit is $3 \mathrm{~km}^{2}$ and it can be followed in continuous outcrop for $c .1 \mathrm{~km}$ along strike. $\mathrm{CB}_{1}$ is $21 \mathrm{~m}$ thick in Parat Kløft and $17 \mathrm{~m}$ thick in Kosmocerasdal and consists of medium- to very coarse-grained sandstones showing weak bioturbation by Skolithos-type burrows. It consists of a single set of progradational clinoforms. The clinoforms are tangential with truncated upper parts and show maximum dip angles of $16^{\circ}$ and migration direction towards the south-east $\left(132^{\circ}\right.$; Fig. 12). The clinoform surfaces bound single sets of trough cross-bedded sandstones.

The geometry of $\mathrm{CB}_{1}$ cannot be determined, but it forms a tabular sandstone body in outcrop. It downlaps onto medium- to coarse-grained shallow marine sandstones and has a sharp truncated top. $\mathrm{CB}_{1}$ is overlain by coarse-grained sandstones at Parat Kløft (locality 2 ) and dark silty mudstones at Kosmocerasdal (locality 1). The mudstones at Kosmocerasdal contain marine dinocysts (assemblage 3; Appendix 1) and a tentative stratigraphic correlation with the established stratigraphic scheme of Jameson Land suggests a Late Bathonian, A. cranocephaloide Chron or older age (Fig. 4; Piasecki 1980). This is supported by an ammonite fragment found in the transgressive lag at the top of $\mathrm{CB}_{1}$ in Kosmocerasdal (Callomon \& Birkelund 1980, fig. 2).

\section{Clinoform unit $\mathrm{CB}_{2}$}

$\mathrm{CB}_{2}$ is dominated by an aggradational clinoform set. It is exposed in the area around Parat Kløft (locality 2) over a minimum area of $3 \mathrm{~km}^{2}$ (Fig. 12). The geometry of $\mathrm{CB}_{2}$ cannot be determined, due to limited exposure. The clinoforms are sigmoidal and show dip angles up to $15^{\circ}$ with a migration direction towards the east $\left(84^{\circ}\right)$ whereas the intrasets show a migration direction towards the south-east $\left(132^{\circ}\right.$; Fig. 12). The sigmoidal clinoforms show a very gradual downlap with a rather thick carbonaceous toeset. Clinoforms bound planar cross-sets, up to $1.8 \mathrm{~m}$ thick, of medium- to coarse-grained sandstones rich in carbonaceous detritus and with scattered silicified wood. Bioturbation is restricted to localised Skolithos isp. burrows. $\mathrm{CB}_{2}$ is capped by a wave-influenced unit and is overlain by trough cross-

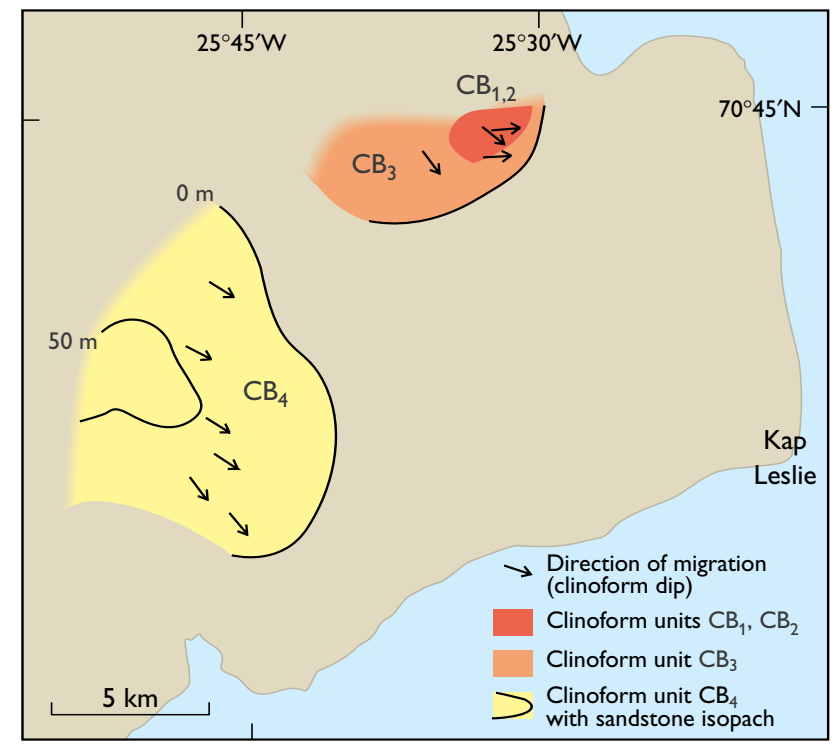

Fig. 12. Isopach map showing thickness variation and geographical distribution of the four clinoform units $\mathrm{CB}_{1}-\mathrm{CB}_{4}$.

bedded, medium- to coarse-grained sandstones with belemnites. The maximum thickness of $\mathrm{CB}_{2}$ is $19.5 \mathrm{~m}$; it is Late Bathonian in age corresponding to the C. calyx and C. apertum Chrons based on dinoflagellate cysts (assemblage 4) found in the fine-grained toeset deposits.

\section{Clinoform unit $\mathrm{CB}_{3}$}

$\mathrm{CB}_{3}$ consists of a single set of progradational clinoforms. The clinoform unit is exposed over $8 \mathrm{~km}^{2}$ at Kosmocerasdal (Figs 1, 12, locality 1) and Parat Kløft (locality 2) where it forms the uppermost unit of the Charcot Bugt Formation. Clinoforms are tangential to sigmoidal and show dip angles up to $20^{\circ}$ with a migration direction towards the east $\left(90^{\circ}\right.$, locality 1$)$ and south-east (136 ${ }^{\circ}$; Figs 1, 12, locality 2 ). Clinoforms bound single sets of trough cross-beds up to $8 \mathrm{~cm}$ thick, and each set can be traced down-dip for several metres. The trough cross-bedded sandstones are medium- to coarse-grained with scattered carbonaceous detritus and kaolinitic mudstone clasts. $\mathrm{CB}_{3}$ shows localised bioturbation (Skolithos isp.) and belemnites occur in the uppermost part of $\mathrm{CB}_{3}$ in Kosmocerasdal (Figs 1, 12 , locality 1 ).

$\mathrm{CB}_{3}$ downlaps onto horizontally bedded or low-angle cross-bedded, medium- to coarse-grained, shallow marine sandstones (facies 4). At Kosmocerasdal, $\mathrm{CB}_{3}$ shows a strongly truncated top and is overlain by a fine-grained sandstone bed, $30 \mathrm{~cm}$ thick, containing 
scattered fine pebbles and abundant coalified wood pieces, whereas it shows a wave-influenced top at Parat Kløft. The sandstones are overlain by sandy siltstones of the Kap Leslie Formation. The clinoform unit has a wedge-shaped geometry with a planar lower surface and an eastwards inclined upper surface. Contours of the upper formation boundary (i.e. the upper boundary of $\mathrm{CB}_{3}$ in this area) show that the surface is planar and dips a few degrees towards the south-east.

Dinoflagellate cysts in the bottomset (assemblage 5) indicate an Early Callovian age corresponding to the C. nordenskjoeldi or earliest $P$. koenigi Chrons. Dinocysts from the basal beds of the overlying Kap Leslie Formation (assemblage 6) indicate the Middle Callovian $S$. calloviense or possibly K. jason Chronozones (Fig. 4; Piasecki 1980). The oldest ammonites present in the overlying mudstone succession are found c. $12 \mathrm{~m}_{\text {above }} \mathrm{CB}_{4}$ and belong to the Upper Callovian P. athleta Chronozone, K. proniae Subchronozone (Callomon \& Birkelund 1980).

\section{Clinoform unit $\mathrm{CB}_{4}$}

Clinoform unit $\mathrm{CB}_{4}$ forms the uppermost part of the Visdal Member in the western outcrop area and is exposed in laterally continuous outcrops between localities 6 and 15 and between localities 4 and 5; it covers at least $40 \mathrm{~km}^{2}$ (Figs 12, 13). The clinoforms downlap onto marine carbonaceous mudstones in most of the area, but it erosionally overlies medium-grained sandstones of the shoreface association in the northern part of Visdal (Fig. 13; localities 11-13). The top of $\mathrm{CB}_{4}$ forms the upper formation boundary and is overlain by silty mudstones of the Kap Leslie Formation (localities 8-13). The Mudderbugt Member erosionally overlies $\mathrm{CB}_{4}$ in the southern part of Visdal (localities 6, 7). The age of $\mathrm{CB}_{4}$ is Early-Middle Oxfordian based on dinoflagellate cysts (assemblage 7) found in the underlying marine mudstones and the carbonaceous toesets that are indicative of the C. cordatum and C. densiplicatum Chronozones (Fig. 4). The age given by the dinoflagellate cyst assemblage is in accordance with ammonites in the overlying Mudderbugt Member (C. densiplicatum Chronozone; Callomon 1961). $\mathrm{CB}_{4}$ shows a lobe-shaped geometry with the maximum thickness in the proximal (western) area (Figs 1, 12, localities 8-13). The gradual decrease in thickness towards the east and south-east can be observed at outcrop between localities 5 and 4 . Around locality 4, thin beds of coarse-grained sandstones are found embedded in offshore mudstones, probably representing the most distal part of the clinoform unit.
Cross-bedded tidal sandstones of facies 10 occur in the proximal (western) part of clinoform unit $\mathrm{CB}_{4}$ and consist of medium- to coarse-grained, generally wellsorted sandstones with abundant disseminated carbonaceous material. Tidally-influenced planar and trough cross-beds up to $1.5 \mathrm{~m}$ thick, (typically $0.30-0.45 \mathrm{~m}$ ) form cosets up to $15 \mathrm{~m}$ thick (Fig. 14). The cosets generally fine upwards and are capped by fine-grained carbonaceous mudstone layers. The planar cross-bedded sets show rhythmic variation in bundle thickness, double mud drapes, and type $\mathrm{B}$ and $\mathrm{C}$ reactivation surfaces indicating tidal influence (de Mowbray \& Visser 1984; Nio \& Yang 1991a). Double mud drapes, less than a few millimetres thick, extend from the bottomsets to approximately two-thirds up the set. Reactivation surfaces dip approximately $23^{\circ}$ as compared to the maximum foreset dip of $26^{\circ}$. Foreset inclinations change systematically, decreasing with decreasing bundle thickness. Palaeocurrent readings from the planar cross-sets indicate a dominant southerly transport direction (mean $176^{\circ}$ ). Small reversed current ripples showing foreset azimuths towards the north climb up the reactivation surfaces and form sets up to $1.5 \mathrm{~cm}$ thick, draped by a layer of carbonaceous mudstone. The tidally-influenced planar cross-beds show bioturbation concentrated along set boundaries and on the foreset laminae (Fig. 14B).

The clinoform sets can be followed between outcrops in the valley of Visdal, and are arranged in a shingled fashion, such that superposed sets are offset in a southwards direction. The clinoform sets in $\mathrm{CB}_{4}$ show all three geometrical styles defined above. The progradational clinoform sets are most common in the central part of Visdal (localities 8 and 9), where they form the lower part of $\mathrm{CB}_{4}$ (Fig. 13). The thick progradational clinoform sets are associated with the maximum thickness of the clinoform unit. The progradational clinoform sets reach a maximum thickness of $29 \mathrm{~m}$ at locality 8 . The clinoforms are tangential, with angles typically varying between $5^{\circ}$ and $20^{\circ}$, although locally up to $24^{\circ}$. The clinoforms bound sandstones showing low-angle trough cross-sets, 3-14 cm thick (Fig. 15).

The aggradational clinoform sets are most common in the northern part of the Visdal valley (localities 11, 12), where the low-angle sigmoidal clinoforms bound sets of planar cross-sets (Fig. 16). Clinoform dip angles are in the range $3-12^{\circ}$. The internal cross-sets are up to $1.5 \mathrm{~m}$ thick. The offlapping clinoform sets occur in the upper half of $\mathrm{CB}_{4}$ and are characteristically massive in appearance. The maximum thickness is $12 \mathrm{~m}$ (locality 9) and the offlapping sets are composed of cosets of low-angle trough cross-beds. 


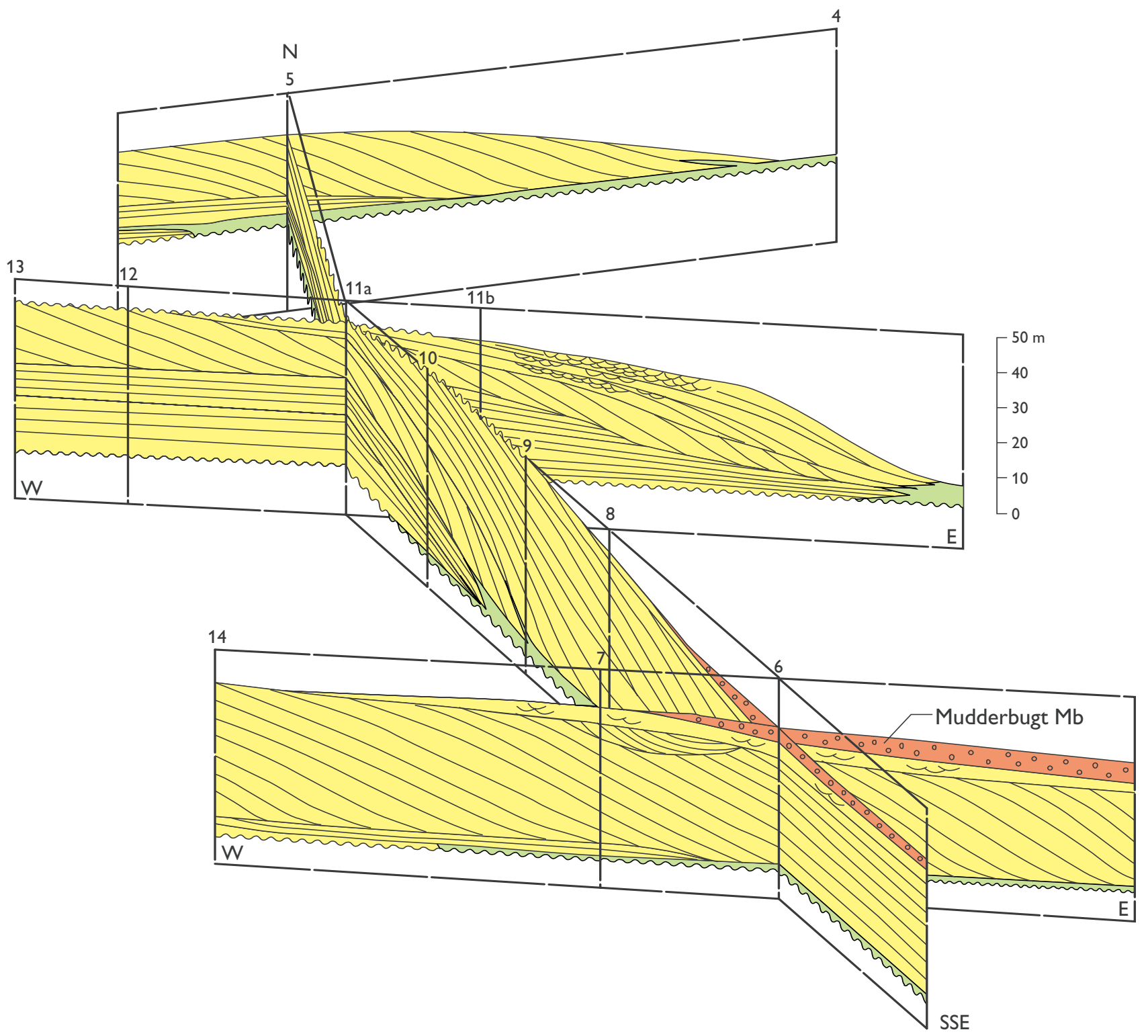

Fig. 13. Fence-diagram of clinoform unit $\mathrm{CB}_{4}$ based on vertical sections at Visdal and Bays Fjelde. The cross-sections are somewhat idealised in order to show the component clinoform sets and the nature of the bounding surfaces. $\mathrm{CB}_{4}$ prograded towards the east and south-east and passes laterally into offshore mudstones (green) of the Kap Leslie Formation. Localities are shown in Fig. 1.

The clinoforms of $\mathrm{CB}_{4}$ show a consistent dip towards the south-east (mean of $123^{\circ}$; Fig. 12), indicating progradation in this direction, slightly oblique to the reconstructed palaeoshoreline. The internal cross-bedding is slightly offset to the south of the progradation direction and shows a mean palaeocurrent direction towards $157^{\circ}$. Clinoform dip angles decrease asymptotically towards the lower boundary and merge into a clinoform toeset unit, several metres thick, rich in carbonaceous detritus. Sigmoidal clinoforms in the upper part merge into a horizontally bedded, wave-influenced clinoform top. It varies in thickness dependent on the amount of truncation and reaches a maximum thickness of $6.6 \mathrm{~m}$ at locality 9. In the southern part of the Visdal valley (locality 7), the upper part of $\mathrm{CB}_{4}$ is truncated by large-scale concave-up erosional surface overlain by steeply dipping avalanche beds. The scour can be followed along strike for more than $1 \mathrm{~km}$ and downdip for approximately $100 \mathrm{~m}$. The dip angle of successive avalanche beds in the scour fill decreases gradually upwards and down-dip from $30^{\circ}$ to $6^{\circ}$.

The top surface of $\mathrm{CB}_{4}$ shows a characteristic proximal (landwards) to distal (basinwards) development. The surface has been walked out in the Visdal area 

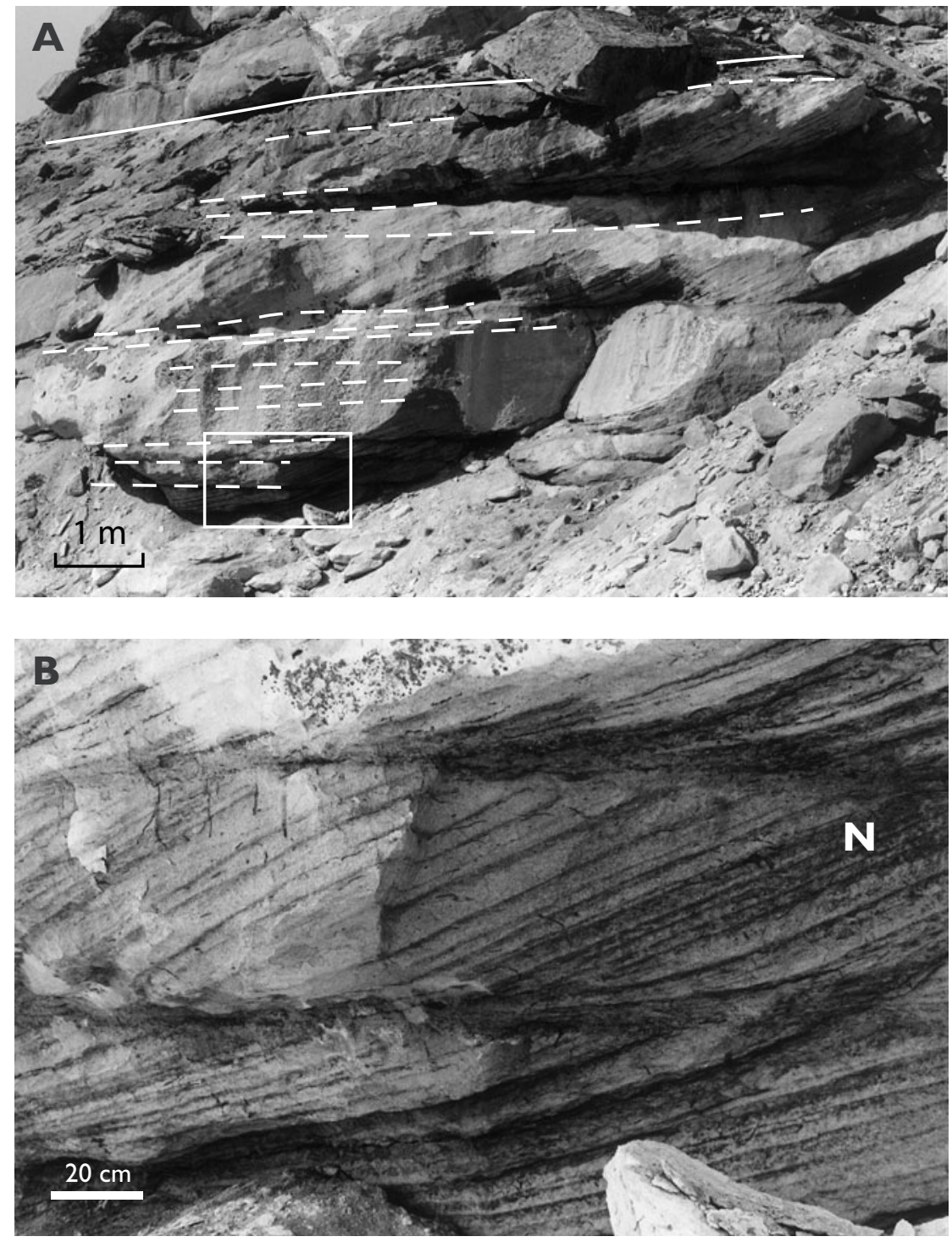

Fig. 14. Sedimentary facies of the prograding wedge association, locality 11, northern Visdal.

A: Coset of tidally-influenced planar cross-bedded sandstones; set boundaires indicated by dashed lines, coset boundary by the solid line. Area outlined shown in detail in Fig. 14B. B: Close-up of tidal cross-beds. Note the variation in bundle thickness interpreted as a cyclic variation controlled by the tidal cycle. Neap-tide bundles (N) are draped by carbonaceous mudstones. Note burrows extending down from set boundaries and at right-angles to the foreset surfaces. Bundle thickness increases and mud-drapes and bioturbation decrease from neap to spring-tide bundles. where it forms a spectacular, and easily recognisable surface separating cliff-forming coarse-grained sandstones from soft silty mudstones (Fig. 2). In northern Visdal, localities 9-15, the surface is planar and roughly horizontal. South of locality 9 , however, the surface dips approximately $6^{\circ}$ towards the south-east. Small remnants of tidally-influenced sandstones erosionally overlie the uppermost prograding wedge association. The preserved thickness of this tidal unit varies along the valley and reaches a maximum of $5.5 \mathrm{~m}$ around locality 7 . The boundary between $\mathrm{CB}_{4}$ and the tidally-influenced cross-sets is locally draped with fine pebbles. At locality $4, \mathrm{CB}_{4}$ wedges out and the flooding surface capping $\mathrm{CB}_{4}$ coalesces with a flooding surface forming the top surface of the underlying sandstone unit. In the proximal area (localities 9-13), the upper boundary of
$\mathrm{CB}_{4}$ is a strongly erosional surface truncating mediumto coarse-grained sandstones. The sandstones immediately beneath the surface are cemented by siderite and show a characteristic reddish weathering colour in the uppermost $5 \mathrm{~cm}$. The surface shows a microrelief of a few centimetres and is covered by a pebble lag, one clast thick (Fig. 17). The pebbles are subrounded to wellrounded, subprismoidal or spherical and consist of quartz and lithic fragments. The long axes are up to 4 $\mathrm{cm}$ long at locality $12,2.5 \mathrm{~cm}$ at locality 11 , and $3 \mathrm{~cm}$ at locality 9 . The clasts form a laterally extensive pavement in the proximal area but are more dispersed basinwards. The trace fossils Skolithos isp. and Monocraterion tentaculatum are common, with long vertical tubes descending from the top surface. 
Fig. 15. A: Prograding clinoform set in Visdal $\left(\mathrm{CB}_{4}\right.$, locality 8$)$ showing clinoforms dipping towards the south-east (to the right). The clinoforms bound sets of small-scale low-angle trough cross-sets. Scale (encircled) is $20 \mathrm{~cm}$ long. B: Close-up of A showing clinoforms (arrows) with internal trough cross-sets. The ripples forming the intrasets migrated at a slightly oblique angle to the progradation direction of the clinoforms. Scale divisions are centimetres.
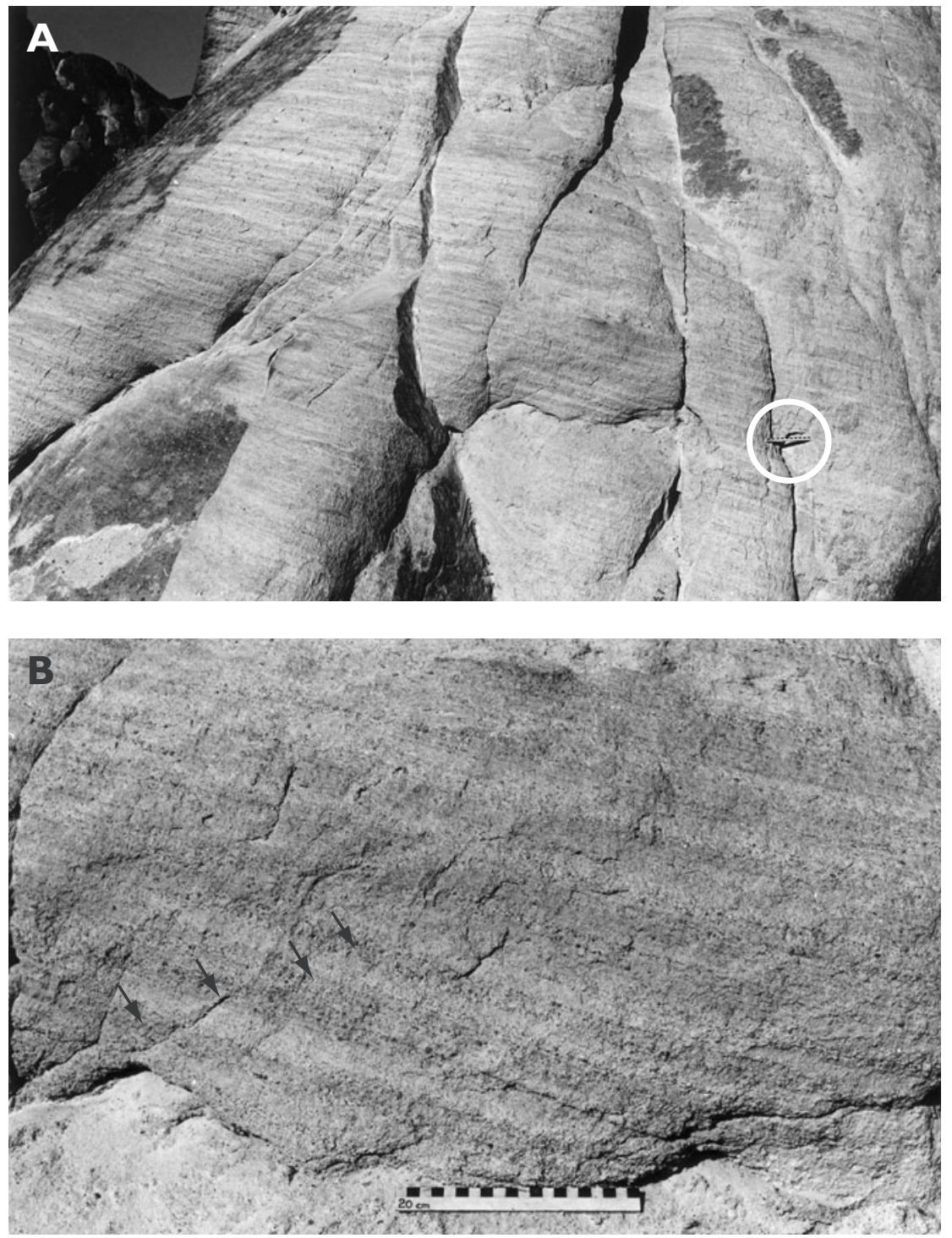

\section{Interpretation}

The deposition of large-scale cross-bedded units in marine settings has been attributed to a number of different depositional settings (see review by Pomar \& Tropeano 2001); a characteristic feature of these deposits is that they comprise coarse-grained laterally extensive bodies encased in fine-grained shelf or offshore deposits. The clinoform units described in this study may be interpreted to have formed by progradation of Gilberttype deltaic lobes or progradational wedges deposited at the shoreface edge (transition-slope deposits of Pomar \& Tropeano 2001). As stressed by Pomar \& Tropeano (2001), however, differentiation between large-scale clinoform units formed as shore-parallel tabular bodies and deltaic (Gilbert-type) lobes is only possible if extensive
3-D data are available. In this study, 3-D outcrops of the individual clinoform units are present in Visdal (Fig. 1), but regionally their large-scale geometry is poorly constrained. We therefore adopt the purely descriptive term clinoform unit for the large-scale cross-bedded sandstone beds rather than using a generic term such as transition-slope lithosome or delta lobe.

The clinoforms represent the depositional surfaces of the prograding wedges at specific times. Progradation was largely controlled by the migration of ripples and dunes transporting sediment across the shelf/delta platform and down the front of the prograding wedge. The migration of these bedforms was at a slightly oblique angle to the main direction of progradation and was probably influenced by southwards-directed longshore currents. Wave influence was rather limited and seems 

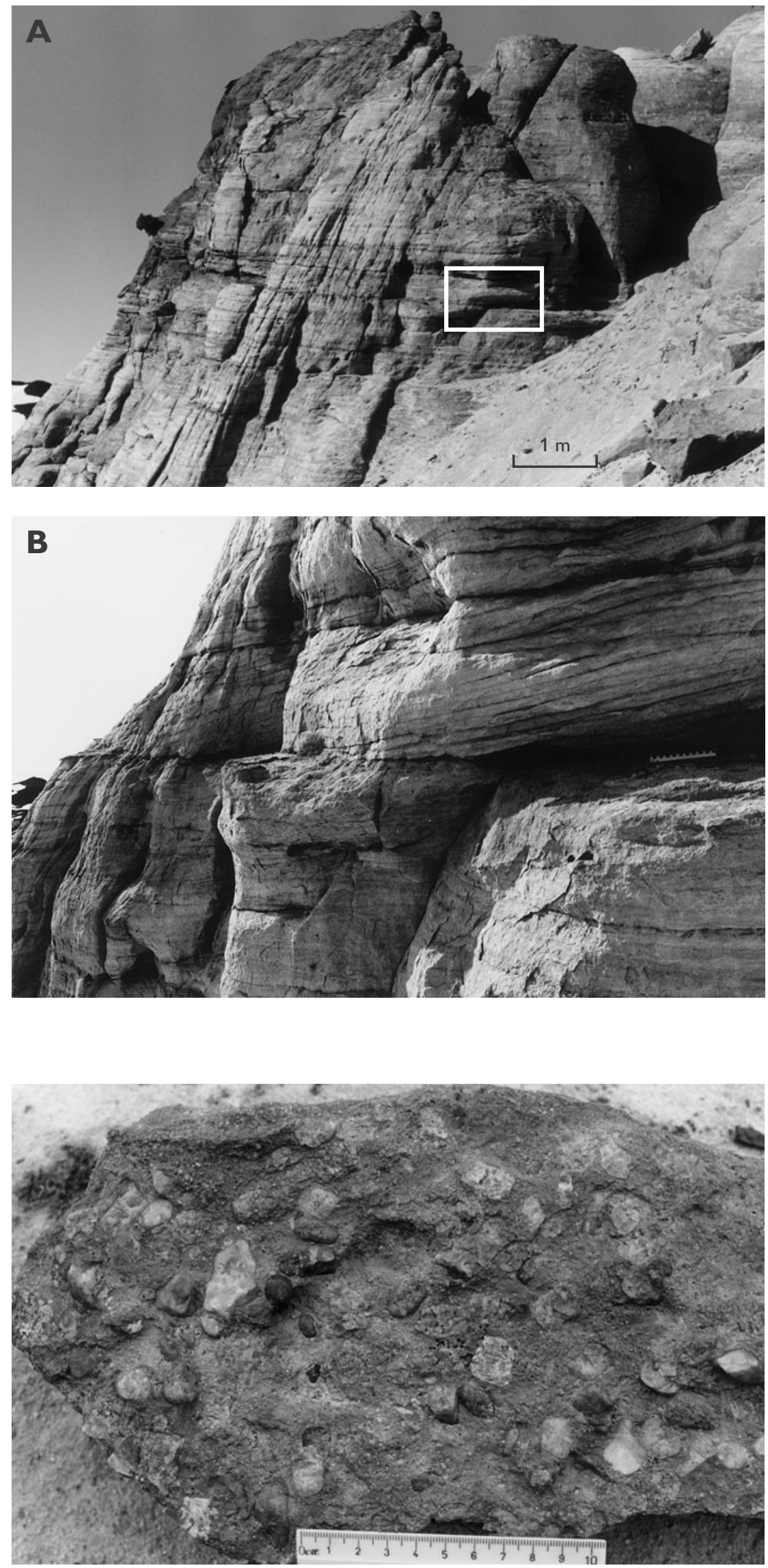

Fig. 16. A: Prograding clinoform set in Visdal ( $\mathrm{CB}_{4}$, locality 9) showing clinoforms dipping towards the viewer in a south-easterly direction. The clinoforms bound small-scale low-angle trough cross-sets and planar cross-sets. Outlined area shown in Fig. 16B. B: Close-up of A showing planar cross-bedded intrasets. Scale is $20 \mathrm{~cm}$ long.
Fig. 17. Pebbly sandstone lag (bedding plane view) deposited on the coalesced sequence boundary and transgressive surface of erosion forming the upper boundary of $\mathrm{CB}_{4}$. Locality 12 , northern Visdal; scale in centimetres. 
only to have influenced deposition in the uppermost part of the clinoform unit, whereas tidal influence was locally strong. The tidal currents were probably restricted to channels and their deposits may be characteristic of certain phases of the progradation event. The base of the prograding wedge (the toe of the clinoforms) was situated below storm wave-base as indicated by the absence of wave-generated structures. The water depth in front of the prograding wedge can be estimated from the thickness of the clinoform unit and was at least $50 \mathrm{~m}$ during the progradation of $\mathrm{CB}_{4}$. The basin floor was dominated by deposition of silt and mud from suspension accompanied by strong bioturbation.

Progradation was not a continuous process, and can be divided into phases based on the different types of clinoform sets (facies 11-13). Each of the clinoform types is thus interpreted to represent a particular progradational phase controlled by autocyclic processes (sediment supply) and/or changes in relative sea level.

The clinoform units $\mathrm{CB}_{1}, \mathrm{CB}_{2}$, and $\mathrm{CB}_{4}$ are dominated by the steep clinoforms of the prograding clinoform sets (facies 11). The rather high angle of the clinoforms is unusual, but such angles have been described as a characteristic feature of bed-load dominated systems prograding during a fall in relative sea level (Posamentier \& Morris 2000). The change in sea level results in erosion of previously deposited sediments and hinders aggradation. This creates a high relief front of the progradational wedge with steeply dipping foresets as the depositional system is forced to prograde into deeper water. The high inclination of the clinoforms is controlled firstly by an abrupt deepening in front of the prograding wedge, secondly by the coarse grain size and thirdly by progradation during falling sea level. Examples of such steeply dipping large-scale foresets have been described from the Recent Alta delta (Norway) in which the foresets dip at angles of 8-37 (Corner et al. 1990), from the Campanian Panther Tongue Member in Utah (Posamentier \& Morris 2000), in which the clinoforms of the delta front are up to $15 \mathrm{~m}$ high and dip at angles up to $27^{\circ}$, and from the Calcarenite di Gravina Formation in southern Italy (Pomar \& Tropeano 2001) which displays large-scale cross-bedding with foreset dips up to $35^{\circ}$.

In $\mathrm{CB}_{4}$, the progradational clinoform sets locally show a gradational upwards change to planar cross-bedded low-angle clinoform sets (facies 12; aggradational). This may reflect the build-up of smaller depositional units on the shelf platform in response to short periods of rising sea level. The platform deposits are capped by a finegrained and strongly bioturbated sandstone unit which represents the abandonment of the depositional system in response to rising sea level or a shift in the current system transporting sediment to the prograding wedge. The progradation of the coarse-grained unit probably took place during a short time interval relative to the accumulation of the fine-grained carbonaceous facies.

The downstepping of successive clinoform sets (facies 13; offlapping) accompanied by erosion of the previously deposited sediments suggests that deposition occurred in response to falling relative sea level. Certain clinoform sets can be followed in outcrop and show a southwards shingling. The southwards migration of the depositional system was probably controlled by southerly-directed currents, which also dominated deposition of the shoreface facies association.

In the proximal western area, the very low-angle depositional surfaces and the well-developed planar cross-sets indicate deposition under the influence of tidal currents. The large-scale planar cross-sets, up to $1.5 \mathrm{~m}$ thick, reflect deposition by large-scale two-dimensional dunes. The dunes are ebb-dominated as shown by the southerly current direction. The reactivation surfaces, systematic changes in bundle thickness and reversed current ripples associated with double mud drapes testify to active tidal currents during dune migrasion and suggest a strongly asymmetric and rectilinear character of the tidal current ellipses (Nio \& Yang 1991a, b). Deposition of mud drapes and formation of reactivation surfaces would be strongly favoured by channelised tidal currents with pronounced slack water periods and a relatively weak wave influence characterising an in-channel depositional environment (Nio \& Yang 1991a, b). The geometry of the channel cannot be recognised but a channel environment is supported by the erosional lower boundary and the fining-upwards and thinning-upwards trends.

\section{Offshore association (facies 8)}

The offshore facies association consists of parallel-laminated silty mudstones with thin sandstone layers and concretionary horizons (facies 8). The association forms the bulk of the Kosmocerasdal Member, representing the distal equivalent to sandstones of the Charcot Bugt Formation (Fig. 4).

\section{Description}

At Kosmocerasdal (Fig. 1, locality 1), the association is characterised by silty and sandy mudstones forming 
coarsening-upwards successions up to $20 \mathrm{~m}$ thick, capped by a sandy bed or a concretionary layer with abundant ammonites. The mudstone succession is otherwise unfossiliferous and bioturbation is rare. The total organic carbon (TOC) content is below 1\% which is characteristic for the lower part (Callovian) of the Kosmocerasdal Member.

At Visdal, the basal few metres of the offshore succession (Middle Oxfordian) consist of black finely laminated mudstones with abundant small Chondrites isp. burrows. Several horizons are glauconitic. Above the basal unit, the succession consists of monotonous mudstone units interbedded with thin layers and concretionary horizons of fine-grained sandstones. Geochemical analysis shows TOC values of 4-7\%, decreasing upwards to less than $1 \%$. Macrofossils are rare and restricted to ammonites and bivalves.

Well-sorted, erosionally based, fine-grained sandstones, up to $c .30 \mathrm{~cm}$ thick, are interbedded with the silty mudstones. The sandstones are highly micaceous and may contain abundant carbonaceous detritus. They are massive or show small-scale wave ripple cross-lamination which passes laterally into hummocky cross-stratification. The sandstones are bioturbated; Skolithos isp. and Taenidium serpentinum are common. Body fossils are common in the sandstones but not in the silty mudstones (Callomon \& Birkelund 1980; Fürsich 1984). This may reflect the nature of the exposures, but may also reflect primary differences in abundance.

\section{Interpretation}

The muds were deposited from suspension fall-out in a marine offshore environment around and below storm wave base, as testified by the fine grain size and the parallel lamination. The sharp-based sandstone beds are interpreted as having been deposited during single storm events whereas the thicker units represent amalgamated deposits formed during successive storms. The well-sorted fine-grained sediment and the small-scale wave ripple cross-lamination associated with hummocky cross-stratified levels suggest deposition on a shoreface between fair-weather and storm wave base (Duke 1985). Comparison with recent shallow marine environments suggests water depths of 15-30 m (Harms et al. 1975, 1982; Dott \& Bourgeois 1982; Brenchley et al. 1986, 1993). The sands were probably transported in suspension by storm-induced currents into the otherwise mud-dominated offshore environment. The fine-grained development of the offshore association at Visdal in the upper C. tenuiserratum and A. glosense Chronozones is also associated with glauconitic horizons, which represent periods of low sedimentation rates. On modern shelves, glauconite is characteristic of sediment-starved offshore environments seawards of the $30 \mathrm{~m}$ isobath (Blatt et al. 1980; Swift \& Parsons 1995).

\section{Facies successions}

Two facies successions representing a basinal (eastern) and proximal (western) position, respectively, are described in order to illustrate changes in the depositional environments through time. Recognition of the facies successions is based on vertical sections; they are shown in the geological cross-section in Figure 18.

\section{The eastern basinal area}

The succession in the eastern, most basinwards position, probably comprises the oldest sediments outcropping in Milne Land (Fig. 4). From below, the succession consists of a poorly exposed unit of the alluvial association overlain by a thick succession of stacked shoreface sandstones. In the better-exposed upper part of the succession three stacked clinoform units $\mathrm{CB}_{1}-\mathrm{CB}_{3}$ occur (Fig. 18). Each of these units represents a seawards shift in facies suggesting that they formed in response to relative falls in sea level (see previous discussion under the prograding wedge association). The stacking of such sand bodies may be controlled by the fixed position of the basin margin or by a change in shoreface gradient due to underlying faults (Jerzykiewicz \& Wojewoda 1986; Trincardi \& Field 1991). The geometries of the clinoform units $\mathrm{CB}_{1}-\mathrm{CB}_{3}$ cannot be ascertained due to limited exposure, but it is possible that they represent laterally extensive sheet-like bodies as described from the Volgian Raukelv Formation of Jameson Land (Surlyk \& Noe-Nygaard 1991) and from the Calcarenite di Gravina Formation of Italy (Pomar \& Tropeano 2001).

The sandstone bodies are truncated by transgressive surfaces of erosion overlain by a ravinement bed (facies 7) containing worn belemnites and vertical burrows of Diplocraterion habichi. In $\mathrm{CB}_{3}$, the pebbly sandstone lag is directly overlain by offshore marine mudstones indicating a marine flooding and a marked landwards shift in facies. Offshore mud deposition continued throughout the Late Callovian - Middle Oxfordian at this locality indicating that the sand-dominated depositional 


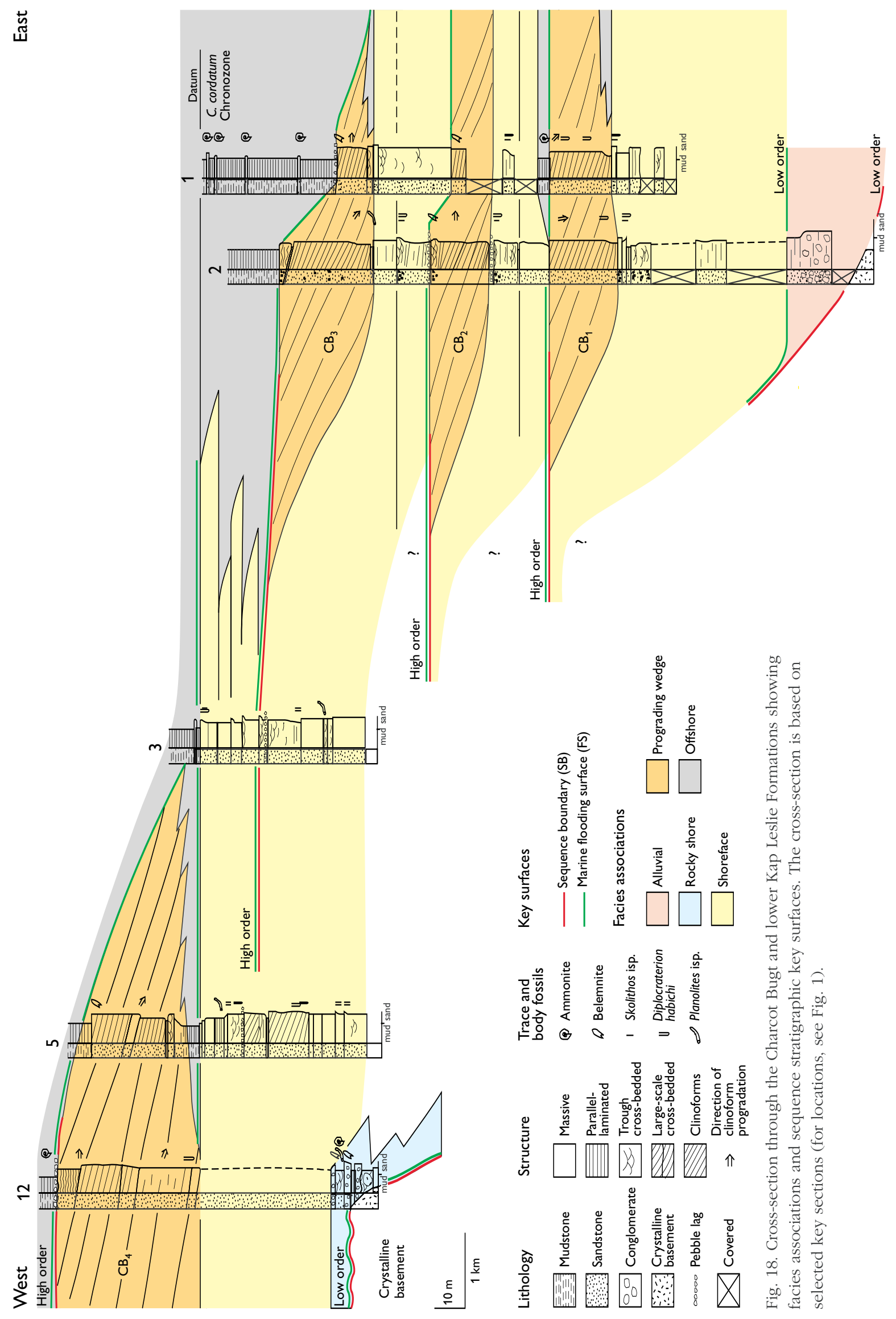


system remained in a more landwards position, probably due to a major rise in relative sea level. It is also possible that a barrier formed by a step in the crystalline basement surface was transgressed in the Late Callovian resulting in a more permanent landwards translation of the sandstone-dominated depositional system, even during a relatively small rise in relative sea level.

\section{The western basin margin}

At Visdal, coarse-grained deposits formed by reworking of alluvial and shoreface deposits during an overall Middle Jurassic transgression dominate the basal part of the Charcot Bugt Formation (Fig. 18). The most characteristic deposit is the coarse-grained rocky shore association which rests either directly on the subaerial unconformity formed by the crystalline basement surface or on a submarine ravinement surface developed on top of alluvial sediments. The coarse-grained deposits represent stacked lags formed by wave ravinement during several sea-level cycles and are time transgressive (see Kidwell 1989). The marine conglomerates are truncated by numerous erosional surfaces, some of which may have formed in response to relative sea-level changes of regional significance. The coarse-grained amalgamated nature of the succession and evidence of local erosion by rip channels and shoaling waves, however, preclude distinction between local and regional surfaces. The nature of the exposures also precludes direct tracing of the erosional surfaces into the shoreface deposits.

A few kilometres seawards of the rocky shore, the deposits are dominated by stacked coarsening-upwards progradational shoreface units forming parasequences or simple sequences (Fig. 18). Within the shoreface units, the transgressive part is subordinate (Arnott 1995) and is only represented by a thin lag conglomerate, which may be overlain by a mudstone unit less than one metre thick. The bulk of the units represent progradational shoreface deposits formed in response to increasing sediment supply or were controlled by changes in relative sea level.

The upper part of the Charcot Bugt Formation at Visdal shows a marked change from the stacked highstand shoreface units to clinoform unit $\mathrm{CB}_{4}$. It reaches a thickness of $50 \mathrm{~m}$ and downlaps onto transgressive mudstones overlying large-scale cross-bedded shoreface deposits (Fig. 18). In the most proximal western areas, the lower boundary cuts deeply into the underlying deposits. Two stacked fining-upwards units that consist exclusively of tidally-influenced cross-sets (facies 10) dominate the overlying deposits and the incision may mark the position of a tidal channel. These deposits are downlapped by high-angle, tangential clinoforms of a progradational clinoform set. $\mathrm{CB}_{4}$ has a lobate plan geometry and wedges out over a few kilometres towards the south-east and east.

The top of clinoform unit $\mathrm{CB}_{4}$ is strongly truncated in the proximal western part where it is overlain by a coarse-grained pebble lag of fluvial affinity. Towards the east, the lag fines and grades into a lag deposit of flat, rounded quartzitic pebbles and worn belemnites that is interpreted to have formed by wave winnowing during marine transgression. $\mathrm{CB}_{4}$ is erosionally overlain by coarse-grained shoreface sandstones (Mudderbugt Member) in the southern part of the Visdal valley.

Following progradation of $\mathrm{CB}_{4}$, the depositional system was drowned and succeeded by offshore marine muds indicating that the sand-dominated depositional system shifted further westwards during the Middle Oxfordian. The mudstones are characterised by small Chondrites isp. burrows and glauconitic horizons, suggesting a sediment-starved, oxygen-restricted environment. Biostratigraphic data show that the offshore mudstones of the lower Kosmocerasdal Member in the eastern outcrop area are contemporaneous with the coarse-grained marine deposits of the Charcot Bugt Formation to the west. The variation in grain size and content of organic material reflect changes in energy regime, sedimentation rates and probably water depths. The coarsening-upwards offshore successions correlate with progradational units in the Charcot Bugt Formation and shallow-water sandstones encountered in the easternmost outcrops correspond to the final progradation of the Charcot Bugt Formation during the C. tenuiserratum Chron (Fig. 4). In contrast, the most fine-grained levels were deposited during periods of increasing water depth. Condensation reflected by high diversity and density of dinocysts and high TOC values are seen in mudstones of the $Q$. lamberti ?, upper Q. mariae - lower C. cordatum and upper C. tenuiserratum - A. glosense Chronozones. Bioturbation during these periods was dominated by Chondrites isp.

\section{Sequence stratigraphic model}

A hierarchy of depositional sequences is recognised in the Middle-Upper Jurassic succession of Milne Land and is related to two, or possibly three, orders of relative sea-level change. The low order cycle has a duration of c. $30 \mathrm{Ma}$ (Bathonian-Volgian) and corresponds 
in duration to the second order cycles of Vail et al. (1977). The higher order cycles of the Charcot Bugt Formation may correspond to third order cycles, although a genetic background for cycle orders has never been demonstrated (see discussion by Miall 1997). The highest order cycles that can be differentiated are related to the internal upbuilding of the clinoform units, although it is difficult to separate sea-level from autocyclic control at this level.

\section{Low order cycle}

The Jurassic - lowermost Cretaceous succession of East Greenland has been interpreted within a low-resolution sequence stratigraphic framework (Surlyk 1990, 1991). The cycle is bounded below by a regional sequence boundary, which in Milne Land coincides with the onlap unconformity between the crystalline basement and the Middle Jurassic sediments. No low order lowstand deposits are preserved along the western basin margin, which was probably bypassed by sediment during most of the Early Jurassic. A rise in relative sea level is reflected by the Bathonian - Middle Oxfordian westwards onlap onto the crystalline basement and by the marked backstepping of the depositional systems. The Charcot Bugt Formation and the lower part of the Kap Leslie Formation are thus interpreted to represent the transgressive deposits of a low order sea-level cycle. The maximum flooding zone is represented by Lower Kimmeridgian laminated organic-rich shales of the Gråkløft Member, Kap Leslie Formation (Birkelund et al. 1984). The sequence is bounded at the top by a major unconformity that is recognised within the sandstone-dominated Hartz Fjeld Formation (Birkelund et al. 1984; Surlyk et al. 1993).

The low order depositional cycle probably reflects increasing rates of subsidence from the onset of rifting in the Late Bajocian to rift climax in the Middle Volgian followed by decreasing subsidence rates accompanying waning of rifting in the latest Volgian - earliest Cretaceous. The regional sea-level cycle correlates with the onset, increase and climax of rifting as recognised throughout the Northern North Sea - North Atlantic region (Ziegler 1988).

\section{High order cycles}

The high order sequence stratigraphic interpretation is based on facies successions and the identification of stratigraphic surfaces across which occur major shifts in facies. The correlation and interpretation of high order cycles are supported by biostratigraphic data, but due to their low resolution we are not able to document hiati across the identified sequence boundaries. A subdivision of the entire succession into a definite number of high order cycles is hampered by exposure quality and lack of correlation between the eastern area (localities 1, 2) and the western area (localities 3-19). In the following, however, we discuss sedimentary successions that we believe formed as a result of high order relative sea-level changes.

The clinoform units $\mathrm{CB}_{1}-\mathrm{CB}_{4}$ unconformably overlie marine shoreface sandstones or offshore mudstones and represent periods of rapid progradation introducing relatively coarse-grained sandstones into more basinal environments. The clinoform units are interpreted as having been formed during falling sea level and possibly early lowstand and define high order sequences. The sandstones may thus be placed in the falling stage systems tract and are capped by the sequence boundary (Hunt \& Tucker 1993, 1995; Plint \& Nummedal 2000). The stacking of $\mathrm{CB}_{1}-\mathrm{CB}_{3}$ in a relatively basinal position and the relatively steep nature of the clinoforms suggests that the clinoform units were deposited in a shelf-edge position and thus mark the maximum progradation during a fall in relative sea level. The clinoform units are truncated by a transgressive surface of erosion concealing a sequence boundary, and are overlain either by a shoreface unit $\left(\mathrm{CB}_{1}, \mathrm{CB}_{2}\right)$ or directly by offshore mudstones $\left(\mathrm{CB}_{3}, \mathrm{CB}_{4}\right)$.

Following progradation of $\mathrm{CB}_{3}$, a marked backstepping of the entire depositional system translated the shoreline far to the west of the present-day outcrop area and deposition in Milne Land was characterised by silty mudstones of the Kosmocerasdal Member. During a subsequent sea-level fall, the clinoform unit $\mathrm{CB}_{4}$ prograded, but did not reach the former position of the shelf-edge. In the proximal areas, the presence of a distinct pebble lag suggests that a fluvial system was developed during the final phase of progradation. The upper part of $\mathrm{CB}_{4}$, however, was reworked during the following transgression and the top of $\mathrm{CB}_{4}$ represents a coalesced sequence boundary and transgressive surface of erosion. The transgressive shoreface deposits of the Mudderbugt Member were formed by reworking of the prograding wedge sands in the southern part of the Visdal valley. The transgressive surface of erosion forming the upper boundary of the Charcot Bugt Formation is overlain by offshore glauconitic marine mudstones of the Kap Leslie Formation which are interpreted to form the transgressive systems tract of the following sequence. 
The boundary between the Charcot Bugt and Kap Leslie Formations appears, at first sight, to represent a single transgressive surface of erosion. Detailed sedimentological and biostratigraphical data show, however, that it represents a system of shingled sub-horizontal transgressive surfaces of erosion (Figs 4, 18). The transgressive surfaces apparently merge basinwards, as suggested by Surlyk (1991) for the boundary between the contemporaneous Pelion and Fossilbjerget Formations in Jameson Land. The understanding of the stratal geometry is crucial for the sequence stratigraphic interpretations and for the correct correlation of genetically linked depositional systems (Posamentier et al. 1992). Marine transgressive surfaces of erosion are the most regionally extensive and continuous surfaces in the Charcot Bugt Formation and some may be traced throughout the entire outcrop. This may be due to their high preservation potential and the fact that marine transgressive erosion commonly removes evidence of subaerial and marine surfaces formed during times of fall and lowstand of sea level leaving only a thin lag deposit (Plint 1988; Posamentier et al. 1992). Wave ravinement is able to remove a significant amount (up to $20 \mathrm{~m}$ ) of the previously deposited succession (Demarest \& Kraft 1987).

The sequence stratigraphic model for the Charcot Bugt - Kap Leslie Formations suggests a marked spatial shift in depocentres of the deposits of the different systems tracts, although each of the facies associations contain facies deposited during both falling and rising relative sea level (Fig. 18). The basinwards eastern area is dominated by stacked falling stage/lowstand sandstone bodies erosionally overlain by thin transgressive lags. Highstand deposits occur, but are thin. In the proximal western areas near the structurally controlled basin margin, transgressive deposits onlap the crystalline basement. They are remarkably coarse-grained and thickly developed due to the steep gradient rocky shore. Alluvial sediments are preserved in topographic lows. These sediments overlie the sequence boundary and are truncated by the transgressive surface of erosion; they thus belong to the lowstand systems tract. Off the rocky shore, the succession is dominated by stacked parasequences representing progradational shoreface units referred to the highstand systems tract (Fig. 18).

\section{Contemporaneous successions}

The Charcot Bugt Formation forms the basin margin correlative of the Pelion, Fossilbjerget and Olympen Formations of Jameson Land. The detailed Middle
Jurassic Boreal ammonite zonation allows direct correlation of the successions and the stacking of depositional units can be shown to be broadly similar (Fig. 19; Engkilde \& Surlyk 2003, this volume; Larsen \& Surlyk 2003 , this volume). Progressive basin margin onlap to the west and north in the basin occurred during deposition of the Upper Bajocian - Lower Bathonian sequences $\mathrm{P} 2$ and P3, accompanied by a northwards shift of the depocentre (P after Pelion Formation, see Engkilde \& Surlyk 2003, this volume). Sequence P3 was deposited during the Early Bathonian A. arcticus Chron and can be correlated with shallow marine sandstones of the basal Charcot Bugt Formation (Fig. 19). Engkilde \& Surlyk (2003, this volume) suggested that sequence P3 correlates with sandstones forming a thick transgressive systems tracts on the islands of Traill $\varnothing$ and Geographical Society $\varnothing$ (Fig. 1). The backstepping of high order sequences and the formation of thick transgressive deposits at the basin margin are thus characteristic features of the Boreal Upper Bajocian - Lower Bathonian Jameson Land Basin (Engkilde \& Surlyk 2003, this volume).

In Milne Land, the Middle Bathonian A. ishmae Chronozone is represented by shoreface sandstones in the lower part of the Charcot Bugt Formation and can be correlated with sequence $\mathrm{P} 4$ in Jameson Land. Deposition of sequences P 4 and P5 of the Vardekløft Group was characterised by backstepping in response to continued sea-level rise. The transgressive systems tract of sequence $\mathrm{P} 5$ is characterised by ammonites of Tethyan affinity suggesting that the transgression may be significant outside East Greenland, opening for oceanic circulation to the south (Callomon 1993; Engkilde \& Surlyk 2003, this volume; Alsen \& Surlyk in press). In Milne Land, the Middle Bathonian A. cranocephaloide Chronozone is represented by a thick rocky shoreline succession, which can be correlated with highstand deposits of sequence P5. Backstepping continued through sequences P6-P8, but was interrupted by a short progradational event reflected in the deposition of the sandy Parnas Member (highstand deposits of P6) in northern Jameson Land (Heinberg \& Birkelund 1984; Engkilde \& Surlyk 2003, this volume). The progradation took place near the boundary between the Lower Callovian C. nordenskjoeldi and P. koenigi Chronozones. This may correlate with the marked progradation of $\mathrm{CB}_{3}$ in Milne Land (Fig. 21).

The maximum transgression recorded in the Vardekløft Group is represented by highly condensed deposits of sequence P8 and the overlying condensed mudstone succession of the Fossilbjerget Formation, which formed 
during the Callovian S. calloviense, K. jason and E. coronatum Chrons (Surlyk et al. 1973; Callomon 1993; Engkilde \& Surlyk 2003, this volume). This transgressive interval correlates with the backstepping of the Charcot Bugt Formation in Milne Land and deposition of the thick mudstone succession of the lower Kosmocerasdal Member (Fig. 19). A renewed progradational phase occurred in Jameson Land in the P. athleta Chron and is represented by deep-water turbidites of the Athene Member of the lower Olympen Formation (Larsen \& Surlyk 2003, this volume). In Milne Land, the succession is poorly documented but may tentatively be correlated with a thick unfossiliferous sandstone succession exposed at Visdal and Aldinger Elv. The sandstones are overlain by carbonaceous mudstones representing a major drowning of the coarse-grained depositional system. The mudstone succession in Milne Land is rich in dinoflagellates and is correlated with the $C$. cordatum Chronozone in Jameson Land. It is represented by a thick mudstone succession in the Hades Member of the Olympen Formation (Fig. 19). The thick clinoform unit $\mathrm{CB}_{4}$ represents the final progradation of the Charcot Bugt Formation in Milne Land. It prograded during the late $C$. cordatum and C. densiplicatum Chrons and correlates with coarse-grained deltaic deposits of the upper Olympen Formation (Fig. 19, Zeus Member; Larsen \& Surlyk 2003, this volume).

The close correlation of the successions in Milne Land and Jameson Land suggests that they were deposited in a major basin covering the entire area. The facies differences probably reflect the position relative to the basin margins and to the main sediment entry points. The marked change from the Bajocian-Callovian ramp setting into the Oxfordian-Kimmeridgian shelfslope setting illustrated by the Pelion, Fossilbjerget and Olympen Formations (Engkilde \& Surlyk 2003, this volume; Larsen \& Surlyk 2003, this volume), is thus not significant in the Milne Land succession where a shallow shelf environment existed throughout the Middle and early Late Jurassic.

Stratigraphic correlation on formation scale between lithostratigraphic units in East Greenland and the North

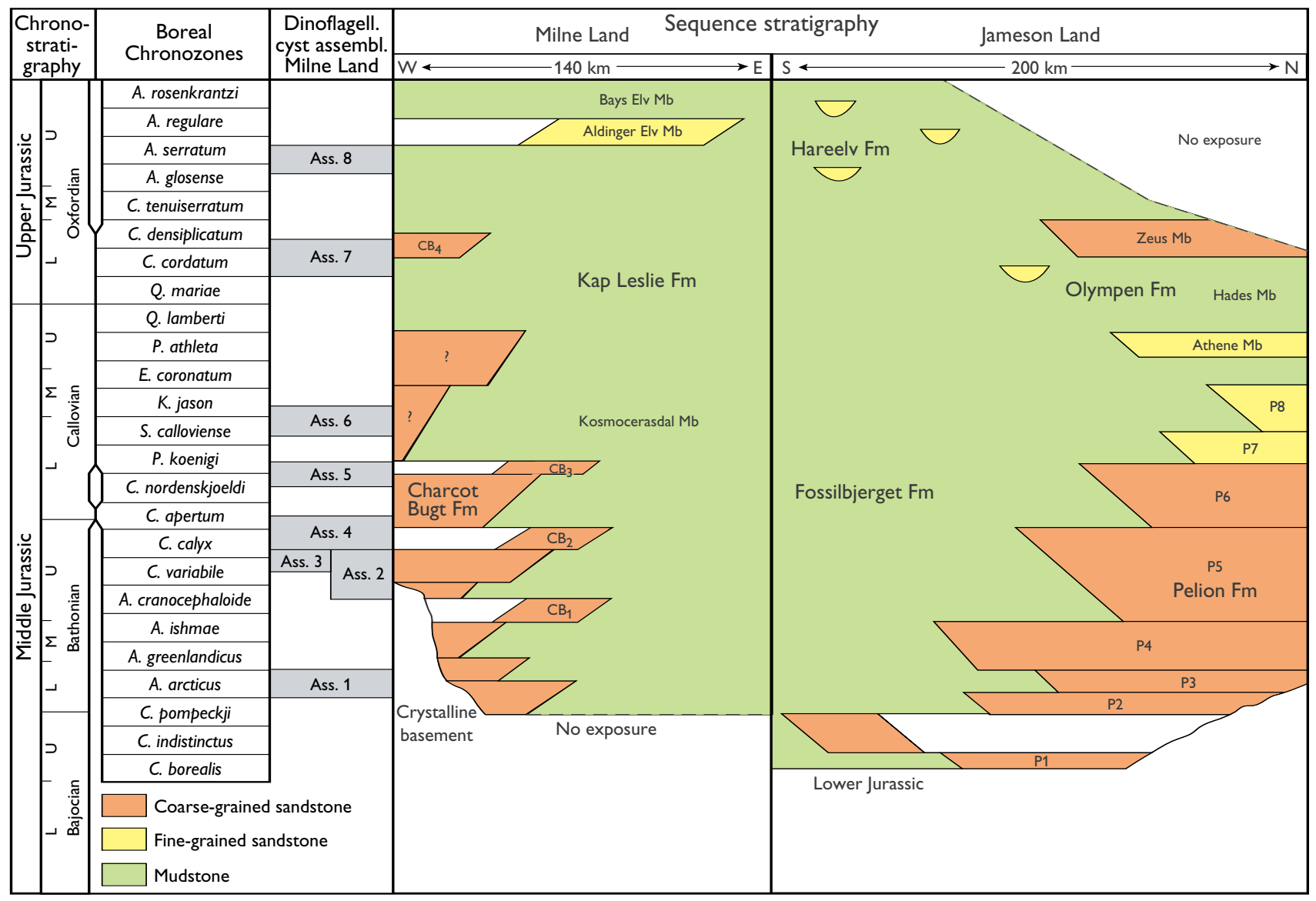

Fig. 19. Sequence stratigraphic model for the Milne Land - Jameson Land successions based on Larsen (1995), Engkilde \& Surlyk (2003, this volume), Larsen \& Surlyk (2003, this volume), and this study. 
Atlantic and the Northern North Sea has been made by numerous authors (e.g. Birkelund 1975; Larsen 1987; Doré 1991; Partington et al. 1993; Dam \& Surlyk 1995, 1998). Surlyk et al. (1993) and Engkilde \& Surlyk (2003, this volume) demonstrated the close similarities between sequence stacking patterns of the Vardekløft Formation in East Greenland and correlative rocks in the North Atlantic region. The coarse-grained falling stage/lowstand sandstone bodies of the Charcot Bugt Formation thus represent an excellent reservoir analogue and may form the basis for developing a new Middle Jurassic stratigraphic play.

\section{Conclusions}

New biostratigraphic data are presented for the Middle and Upper Jurassic succession of Milne Land based on ammonite collections and palynology. Correlation of the coarse-grained sandstones of the Charcot Bugt with the fine-grained offshore Kap Leslie Formation suggests a genetic depositional relationship with a proximal to distal decrease in grain size.

A widespread transgression in East Greenland took place following a major uplift period in late Early Jurassic - earliest Middle Jurassic times and the coarse-grained amalgamated deposits of the basal Charcot Bugt Formation were deposited in front of a steep rocky shore. Estimates of the Middle Jurassic relative sea-level rise are based on contour maps of the onlap surface between crystalline basement and shallow marine sediments. An overall sea-level rise of more than $300 \mathrm{~m}$ is documented, which is independent of sediment supply except for the loading effects.

The most characteristic facies is represented by clinoform units up to $52 \mathrm{~m}$ thick with compound clinoforms dipping up to $24^{\circ}$. The clinoform units consist of coarse-grained, locally pebbly sandstones forming a progradational wedge deposited during falling relative sea level. The unusually steep clinoforms are probably a function of the coarse grain size and high progradation rates into a relatively deep-water basinal setting.

A sequence stratigraphic interpretation involving two orders of sea-level cycles is presented based on spatial changes in depositional systems (facies associations), the nature of bounding surfaces and biostratigrapic data. This model suggests that lateral shifts in depocentres are related to changes in the relative sea level. Thus, falling stage/lowstand prograding wedges occur to the east in a relatively distal position and are encased in distal shoreface and offshore deposits.

\section{Acknowledgements}

M.L. gratefully acknowledges the Carlsberg Foundation for funding of a Ph.D. stipendium and field work in East Greenland (91-0683/20, 92-0505/20, 93-0735/20). The stratigraphic analysis was supported by the Danish Energy Agency, EFP93/0010 and 0017. F.S. acknowledges generous support from the Carlsberg Foundation, the Danish Natural Science Research Council and Norsk Hydro a.s. We thank John H. Callomon, University College, London for invaluable identification of the ammonites. The work benefited from numerous discussions and suggestions by Michael Engkilde and Gregers Dam. We wish to thank the referees Tom Dreyer and Dale Leckie for their constructive comments.

\section{References}

Aldinger, H. 1935: Geologische Beobachtungen im Oberen Jura des Scoresbysundes (Ostgrönland). Meddelelser om Grønland 99, 128 pp.

Alsen, P. \& Surlyk, F. in press: Maximum Middle Jurassic transgression in East Greenland: evidence from new ammonite finds, Bjørnedal, Traill $\varnothing$. In: Stemmerik, L. \& Stouge, S. (eds): The Jurassic of North-East Greenland. Geological Survey of Denmark and Greenland Bulletin.

Arnott, R.W.C. 1995: The parasequence definition - are transgressive deposits inadequately addressed? Journal of Sedimentary Research B65, 1-6.

Bay, E. 1895: Den Østgrønlandske Expedition. VI. Geologi. Meddelelser om Grønland 19, 147-187.

Berné, S., Durand, J. \& Weber, O. 1991: Architecture of modern subtidal dunes (sand waves), Bay of Bourgneuf, France. In: Miall, A.D. \& Tyler, N. (eds): The three-dimensional facies architecture of terrigenous clastic sediments and its implication for hydrocarbon discovery and recovery. SEPM (Society for Sedimentary Geology) Concepts in Sedimentology and Paleontology 3, 245-260.

Birkelund, T. 1975: A review of the Jurassic of East Greenland. In: Finstad, K.G. \& Selley, R.C. (coordinators): Jurassic Northern North Sea Symposium, Stavanger, 28-30 September, 1975. Norwegian Petroleum Society (NPF) Proceedings JNNS/6, $1-27$.

Birkelund, T. \& Callomon, J.H. 1985: The Kimmeridgian ammonite faunas of Milne Land, central East Greenland. Bulletin Grønlands Geologiske Undersøgelse 153, 56 pp.

Birkelund, T., Callomon, J.H. \& Fürsich, F.T. 1984: The stratigraphy of the Upper Jurassic and Lower Cretaceous sediments of Milne Land, central East Greenland. Bulletin Grønlands Geologiske Undersøgelse 147, 56 pp.

Blatt, H., Middleton, G. \& Murray, R. 1980: Origin of sedimentary rocks, 2nd edition, $782 \mathrm{pp}$. New Jersey, USA: Prentice-Hall.

Brenchley, P.J., Romano, M. \& Guiterrez, M.J.C. 1986: Proximal and distal hummocky cross-stratified facies on a wide 
Ordovician shelf in Iberia. In: Knight, R.J. \& McLean, J.R. (eds): Shelf sands and sandstones. Canadian Society of Petroleum Geologists Memoir 11, 241-256.

Brenchley, P.J., Pickerill, R.K. \& Stromberg, S.G. 1993: The role of wave reworking on the architecture of storm sandstone facies, Bell Island Group (Lower Ordovician), eastern Newfoundland. Sedimentology 40, 359-382.

Bucher-Nurminen, K. 1979: The migmatites, granites and metasediments of Danmark $\varnothing$ and adjacent areas of Milne Land and Gåseland, East Greenland Caledonian fold belt. Rapport Grønlands Geologiske Undersøgelse 84, 36 pp.

Callomon, J.H. 1959: The ammonite zones of the Middle Jurassic beds of East Greenland. Geological Magazine 96, 505-513.

Callomon, J.H. 1961: The Jurassic System in East Greenland. In: Raasch, G.O. (ed.): Geology of the Arctic 1, 258-268. Toronto: University of Toronto Press.

Callomon, J.H. 1972: The Jurassic System. In: Callomon, J.H., Donovan, D.T. \& Trumpy, R. (eds): An annotated map of the Permian and Mesozoic formations of East Greenland. Meddelelser om Grønland 168, 15-21.

Callomon, J.H. 1993: The ammonite succession in the Middle Jurassic of East Greenland. Bulletin of the Geological Society of Denmark 40, 83-113.

Callomon, J.H. 2003: The Middle Jurassic of western and northern Europe: its subdivisions, geochronology and correlations. In: Ineson, J.R. \& Surlyk, F. (eds): The Jurassic of Denmark and Greenland. Geological Survey of Denmark and Greenland Bulletin 1, 61-73 (this volume).

Callomon, J.H. \& Birkelund, T. 1980: The Jurassic transgression and the mid-late Jurassic succession in Milne Land, central East Greenland. Geological Magazine 117, 211-226.

Clifton, H.E. 1969: Beach lamination: nature and origin. Marine Geology 7, 553-559.

Clifton, H.E. 1981: Progradational sequences in Miocene shoreline deposits, southeastern Caliente Range, California. Journal of Sedimentary Petrology 51, 165-184.

Corner, G.D., Nordahl, E., Munch-Ellingsen, K. \& Robertsen, K.R. 1990: Morphology and sedimentology of an emergent fjordhead Gilbert-type delta: Alta delta, Norway. In: Colella, A. \& Prior, D.B. (eds): Coarse-grained deltas. International Association of Sedimentologists Special Publication 10, 155-168.

Curtis, C.D. 1990: Aspects of climatic influence on the clay mineralogy and geochemistry of soils, palaeosols and clastic sedimentary rocks. Journal of the Geological Society (London) 147, 351-357.

Dam, G. 1990: Palaeoenvironmental significance of trace fossils from the shallow marine Lower Jurassic Neill Klinter Formation, East Greenland. Palaeogeography, Palaeoclimatology, Palaeoecology 19, 221-248.

Dam, G. \& Surlyk, F. 1995: Sequence stratigraphic correlation of Lower Jurassic shallow marine and paralic successions across the Greenland-Norway seaway. In: Steel, R.J. et al. (eds): Sequence stratigraphy on the Northwest European margin. Norwegian Petroleum Society (NPF) Special Publication 5, 483-509.

Dam, G. \& Surlyk, F. 1998: Stratigraphy of the Neill Klinter Group; a Lower - lower Middle Jurassic tidal embayment succession,
Jameson Land, East Greenland. Geology of Greenland Survey Bulletin 175, 80 pp.

Demarest, J.M. \& Kraft, J.C. 1987: Stratigraphic record of Quaternary sea levels: Implications for more ancient strata. In: Nummedal, D., Pilkey, O.H. \& Howard, J.D. (eds): Sea-level fluctuation and coastal evolution. Society of Economic Paleontologists and Mineralogists Special Publication 41, 223-239.

de Mowbray, T. \& Visser, M.J. 1984: Reactivation surfaces in subtidal channel deposits, Oosterschelde, southwest Netherlands. Journal of Sedimentary Petrology 54, 811-824.

Doré, A.G. 1991: The structural foundation and evolution of Mesozoic seaways between Europe and the Arctic. Palaeogeography, Palaeoclimatology, Palaeoecology 87, 441-492.

Dott, R.H. 1974: Cambrian tropical storm waves in Wisconsin. Geology 2, 243-246.

Dott, R.H. \& Bourgeois, J. 1982: Hummocky stratification: significance of its variable bedding sequences. Geological Society of America Bulletin 93, 663-680.

Duke, W.L. 1985: Hummocky cross-stratification, tropical hurricanes, and intense winter storms. Sedimentology 32, 167-194.

Dupré, W.R., Clifton, H.E. \& Hunter, R.E. 1980: Modern sedimentary facies of the open Pacific coast and Pleistocene analogs from Monterey Bay, California. In: Field, M.E. et al. (eds): Proceedings of the Quaternary depositional environments of the Pacific Coast. Pacific Coast Paleogeography Symposium 4, 105-120.

Engkilde, M. \& Surlyk, F. 2003: Shallow marine syn-rift sedimentation: Middle Jurassic Pelion Formation, Jameson Land, East Greenland. In: Ineson, J.R. \& Surlyk, F. (eds): The Jurassic of Denmark and Greenland. Geological Survey of Denmark and Greenland Bulletin 1, 813-863 (this volume).

Fensome, R.A. 1979: Dinoflagellate cysts and acritarchs from the Middle and Upper Jurassic of Jameson Land, East Greenland. Bulletin Grønlands Geologiske Undersøgelse 132, 98 pp.

Field, M.E., Nelson, C.H., Cacchione, D.A. \& Drake, D.E. 1981: Sand waves on an epicontinental shelf: northern Bering Sea. Marine Geology 42, 233-258.

Flemming, B.W. 1978: Underwater sand dunes along the southeast African continental margin - observations and implications. Marine Geology 26, 177-198.

Frey, R.W. \& Seilacher, A. 1980: Uniformity in marine invertebrate ichnology. Lethaia 13, 183-207. Oslo: Universitetsforlaget.

Fürsich, F.T. 1984: Benthic macroinvertebrate associations from the Boreal Upper Jurassic of Milne Land, central East Greenland. Bulletin Grønlands Geologiske Undersøgelse 149, 72 pp.

Fürsich, F.T. \& Heinberg, C. 1983: Sedimentology, biostratinomy, and palaeoecology of an Upper Jurassic offshore sand bar complex. Bulletin of the Geological Society of Denmark 32, 67-95.

Håkansson, E., Birkelund, T., Heinberg, C. \& Willumsen, P. 1971 Preliminary results of mapping the Upper Jurassic and Lower Cretaceous sediments of Milne Land. Rapport Grønlands Geologiske Undersøgelse 37, 32-41.

Harms, J.C., Southard, J.B., Spearing, D.R. \& Walker, R.G. 1975: Depositional environments as interpreted from primary sedimentary structures and stratification sequences. Society of Economic Paleontologists and Mineralogists Short Course 2, $45-61$. 
Harms, J.C., Southard, J.B. \& Walker, R.G. 1982: Structures and sequences in clastic rocks. Society of Economic Paleontologists and Mineralogists Short Course 9, 249 pp (chapters paginated individually).

Henriksen, N. \& Higgins, A.K. 1988: Geological maps of Greenland, 1:100 000, Rødefjord $70 \varnothing .3$ Nord and Kap Leslie $70 \varnothing .2$ Nord. Descriptive text, 34 pp., 2 maps. Copenhagen: Geological Survey of Greenland.

Heinberg, C. \& Birkelund, T. 1984: Trace fossil assemblages and basin evolution of the Vardekløft Formation (Middle Jurassic, central East Greenland). Journal of Paleontology 58, 362-397.

Hunt, D. \& Tucker, M.E. 1993: Sequence stratigraphy of carbonate shelves with an example from the mid-Cretaceous (Urgonian) of southeast France. International Association of Sedimentologists Special Publication 18, 307-341.

Hunt, D. \& Tucker, M.E. 1995: Stranded parasequences and the forced regressive wedge systems tract: deposition during baselevel fall - reply. Sedimentary Geology 95, 147-160.

Jerzykiewicz, T. \& Wojewoda, J. 1986: The Radków and Szczeliniec sandstones: an example of giant foresets on a tectonically controlled shelf of the Bohemian Cretaceous basin (central Europe). In: Knight, R.J. \& McLean, J.R. (eds): Shelf sands and sandstones. Canadian Society of Petroleum Geologists Memoir 11, 1-15.

Kidwell, S.M. 1989: Stratigraphic condensation of marine transgressive records: origin of major shell deposits in the Miocene of Maryland. Journal of Geology 97, 1-24.

Kleinspehn, K.L., Steel, R.J., Johannessen, E. \& Netland, A. 1984: Conglomeratic fan-delta sequences, Late Carboniferous - Early Permian, western Spitsbergen. In: Koster, E.H. \& Steel, R.J. (eds): Sedimentology of gravels and conglomerates. Canadian Society of Petroleum Geologists Memoir 10, 279-294.

Larsen, M. 1995: Facies architecture and sequence stratigraphy of basement-onlapping shallow marine sandstones, the Charcot Bugt Formation, Middle Jurassic, East Greenland 1, 2, 199 pp. Unpublished Ph.D. thesis, University of Copenhagen, Denmark.

Larsen, M. \& Surlyk, F. 2003: Shelf-edge delta and slope deposition in the Upper Callovian - Middle Oxfordian Olympen Formation, East Greenland. In: Ineson, J.R. \& Surlyk, F. (eds): The Jurassic of Denmark and Greenland. Geological Survey of Denmark and Greenland Bulletin 1, 931-948 (this volume).

Larsen, V.B. 1987: A synthesis of tectonically-related stratigraphy in the North Atlantic - Arctic region from Aalenian to Cenomanian time. Norsk Geologisk Tidsskrift 67, 281-293.

Leithold, E.L. \& Bourgeois, J. 1984: Characteristics of coarsegrained sequences deposited in nearshore, wave-dominated environments - examples from the Miocene of south-west Oregon. Sedimentology 31, 746-775.

Lowe, D.R. 1979: Sediment gravity flows: their classification and some problems of application to natural flows and deposits. Society of Economic Paleontologists and Mineralogists Special Publication 27, 75-82.

Lowe, D.R. 1982: Sediment gravity flows: II. Depositional models with special reference to the deposits of high-density turbidity currents. Journal of Sedimentary Petrology 52, 279-297.

McCave, I.N. 1971: Sand waves in the North Sea off the coast of Holland. Marine Geology 10, 199-225.
Miall, A.D. 1977: A review of the braided river depositional environment. Earth Science Reviews 13, 1-62.

Miall, A.D. 1978: Lithofacies types and vertical profile models in braided river deposits. A summary. In: Miall; A.D. (ed.): Fluvial sedimentology. Canadian Society of Petroleum Geologists Memoir 5, 597-604.

Miall, A.D. 1997: The geology of stratigraphic sequences, 433 pp. Berlin: Springer-Verlag.

Mitchum, R.M., Vail, P.R. \& Sangree, J.B. 1977: Seismic stratigraphy and global changes of sea level, Part 6: stratigraphic interpretation of seismic reflection patterns in depositional sequences. In: Payton, C.E. (ed.): Seismic stratigraphy - applications to hydrocarbon exploration. American Association of Petroleum Geologists Memoir 26, 117-133.

Nemec, W. \& Steel, R.J. 1984: Alluvial and coastal conglomerates: their significant features and some comments on gravelly mass-flow deposits. In: Koster, E.H. \& Steel, R.J. (eds): Sedimentology of gravels and conglomerates. Canadian Society of Petroleum Geologists Memoir 10, 1-32.

Nio, S.D. \& Yang, C.S. 1991a: Diagnostic attributes of clastic tidal deposits: a review. In: Smith, D.G. et al. (eds): Clastic tidal sedimentology. Canadian Society of Petroleum Geologists Memoir 16, 3-27.

Nio, S.D. \& Yang, C.S. 1991b: Sea-level fluctuations and the geometric variability of tide-dominated sandbodies. Sedimentary Geology 70, 161-193.

Nummedal, D. \& Swift, D.J.P. 1987: Transgressive stratigraphy at sequence-bounding unconformities: some principles derived from Holocene and Cretaceous examples. In: Nummedal, D., Pilkey, O.H. \& Howard, J.D. (eds): Sea-level fluctuation and coastal evolution. Society of Economic Paleontologists and Mineralogists Special Publication 41, 241-260.

Partington, M.A., Copestake, P., Mitchener, B.C. \& Underhill, J.R. 1993: Biostratigraphic calibration of genetic stratigraphic sequences in the Jurassic - lowermost Cretaceous (Hettangian to Ryazanian) of the North Sea and adjacent areas. In: Parker, J.R. (ed.): Petroleum geology of Northwest Europe: proceedings of the 4th conference, 371-386. London: Geological Society.

Piasecki, S. 1979: Hauterivian dinoflagellate cysts from Milne Land, East Greenland. Bulletin of the Geological Society of Denmark 28, 31-37.

Piasecki, S. 1980: Middle to Late Jurassic dinoflagellate cyst stratigraphy from Milne Land and Jameson Land (East Greenland) correlated with ammonite stratigraphy, 167 pp. Unpublished Ph.D. thesis, University of Copenhagen, Denmark.

Plint, A.G. 1988: Sharp-based shoreface sequences and 'offshore bars' in the Cardium Formation of Alberta: their relationship to relative changes in sea level. In: Wilgus, C.K. et al. (eds): Sea-level changes - an integrated approach. Society of Economic Paleontologists and Mineralogists Special Publication 42, 357-370.

Plint, A.G. \& Nummedal, D. 2000: The falling stage systems tract: recognition and importance in sequence stratigraphic analysis. In: Hunt, D. \& Gawthorpe, R.L. (eds): Sedimentary responses to forced regressions. Geological Society Special Publication (London) 172, 1-17.

Pomar, L. \& Tropeano, M. 2001: The Calcarenite di Gravina 
Formation in Matera (southern Italy): new insights for coarsegrained, large-scale, cross-bedded bodies encased in offshore deposits. American Association of Petroleum Geologists Bulletin 85, 661-689.

Posamentier, H.W. \& Morris, W.R. 2000: Aspects of the stratal architecture of forced regressive deposits. In: Hunt, D. \& Gawthorpe, R.L. (eds): Sedimentary responses to forced regressions. Geological Society Special Publication (London) 172, 19-46.

Posamentier, H.W., Allen, G.P., James, D.P. \& Tesson, M. 1992: Forced regressions in a sequence stratigraphic framework: concepts, examples and exploration significance. American Association of Petroleum Geologists Bulletin 76, 1687-1709.

Retallack, G.J. 1990: Soils of the past. An introduction to paleopedology, 520 pp. Boston: Unwin Hyman.

Rosenkrantz, A. 1929: Preliminary account of the geology of the Scoresby Sound district. Meddelelser om Grønland 73(2), $135-154$.

Rust, B.R. 1978: A classification of alluvial channel systems. In: Miall; A.D. (ed.): Fluvial sedimentology. Canadian Society of Petroleum Geologists Memoir 5, 187-198.

Smelror, M. 1988: Bathonian to Early Oxfordian dinoflagellate cysts and acritarchs from Kong Karls Land, Svalbard. Review of Palaeobotany and Palynology 56, 275-304.

Spath, L.F. 1935: The Upper Jurassic invertebrate faunas of Cape Leslie, Milne Land. I. Oxfordian and Lower Kimmeridgian. Meddelelser om Grønland 99(2), 82 pp.

Spath, L.F. 1936: The Upper Jurassic invertebrate faunas of Cape Leslie, Milne Land. II. Upper Kimmeridgian and Portlandian. Meddelelser om Grønland 99(3), 180 pp.

Surlyk, F. 1990: Timing, style and sedimentary evolution of Late Palaeozoic - Mesozoic extensional basins of East Greenland. In: Hardman, R.F.P. \& Brooks, J. (eds): Tectonic events responsible for Britain's oil and gas reserves. Geological Society Special Publication (London) 55, 107-155.

Surlyk, F. 1991: Sequence stratigraphy of the Jurassic - lowermost Cretaceous of East Greenland. American Association of Petroleum Geologists Bulletin 75, 1468-1488.

Surlyk, F. 2003: The Jurassic of East Greenland: a sedimentary record of thermal subsidence, onset and culmination of rifting. In: Ineson, J.R. \& Surlyk, F. (eds): The Jurassic of Denmark and Greenland. Geological Survey of Denmark and Greenland Bulletin 1, 659-722 (this volume).

Surlyk, F. \& Christensen, W.K. 1974: Epifaunal zonation on an Upper Cretaceous rocky coast. Geology 2, 529-534.

Surlyk, F. \& Noe-Nygaard, N. 1991: Sand bank and dune facies architecture of a wide intracratonic seaway: Late Jurassic - Early Cretaceous Raukelv Formation, Jameson Land, East Greenland.
In: Miall, A.D. \& Tyler; N. (eds): The three-dimensional facies architecture of terrigenous clastic sediments, and its implication for hydrocarbon discovery and recovery. SEPM (Society for Sedimentary Geology). Concepts in Sedimentology and Paleontology 3, 261-276.

Surlyk, F., Callomon, J.H., Bromley, R.G. \& Birkelund, T. 1973 Stratigraphy of the Jurassic - Lower Cretaceous sediments of Jameson Land and Scoresby Land, East Greenland. Bulletin Grønlands Geologiske Undersøgelse 105, 76 pp.

Surlyk, F., Hurst, J.M., Marcussen, C., Piasecki, S., Rolle, F., Scholle, P., Stemmerik, L. \& Thomsen, E. 1984: Oil geological studies in the Jameson Land basin, East Greenland. Rapport Grønlands Geologiske Undersøgelse 120, 85-90.

Surlyk, F., Hurst, J.M., Piasecki, S., Rolle, F., Scholle, P.A., Stemmerik, L. \& Thomsen, E. 1986: The Permian of the western margin of the Greenland Sea - a future exploration target. In: Halbouty, M.E. (ed.): Future petroleum provinces of the world. American Association of Petroleum Geologists Memoir 40, 629-659.

Surlyk, F., Noe-Nygaard, N. \& Dam, G. 1993: High and low resolution sequence stratigraphy in lithological predictions examples from the Mesozoic around the northern North Atlantic. In: Parker, J.R. (ed.): Petroleum geology of Northwest Europe: proceedings of the 4th conference, 199-213. London: Geological Society.

Swift, D.J.P. 1968: Coastal erosion and transgressive stratigraphy. Journal of Geology 76, 444-456.

Swift, D.J.P. \& Parsons, B.S. 1995: Highstand versus lowstand sequence architecture in the Campanian of Wyoming, USA. Sedimentary responses to forced regressions: recognition, interpretation and reservoir potential, Geological Society, London, 7-9 September 1995. Programme with abstracts, $28-30$

Sydow, J. \& Roberts, H.H. 1994: Stratigraphic framework of a Late Pleistocene shelf-edge delta, northeast of Mexico. American Association of Petroleum Geologists Bulletin 78, 1276-1312.

Trincardi, F. \& Field, M.E. 1991: Geometry, lateral variation and preservation of down-lapping regressive shelf deposits: eastern Terrhenian Sea margin, Italy. Journal of Sedimentary Petrology 61, 775-790.

Vail, P.R., Mitchum, R.M. \& Thompson, S. 1977: Seismic stratigraphy and global changes of sea level; Part 4: global cycles of relative changes of sea level. In: Payton, C.E. (ed.): Seismic stratigraphy - applications to hydrocarbon exploration. American Association of Petroleum Geologists Memoir 26, 83-97.

Ziegler, P.A. 1988: Evolution of the Arctic - North Atlantic and the western Tethys. American Association of Petroleum Geologists Memoir 43, 198 pp. 


\section{Appendix 1: Dinoflagellate cyst assemblages}

\section{Assemblage 1}

Ammonite stratigraphy. A. arcticus Chronozone (Jameson Land fauna 9-10; Jameson Land faunas defined by Callomon 1993) or slightly older.

Samples. Samples 409552, 409553 and 409554 were collected from silty mudstones below the horizon containing ammonites of the A. arcticus Chronozone at locality 8 in Visdal (Fig. 6).

Description. The assemblage comprises Crussolia perireticulata, Lithodinia cf. reticulata, Solisphaeridium ankyleton, Pareodinia 'birkelundia', Sentusidinium pelionense, Dichadogonyaulax sellwoodii, Durotrigia daveyi, Kallosphaeridium hypornatum, Pareodinia halosa and Sirmiodinium grossii. The assemblage is of low density and diversity. In Jameson Land, most of these morphologically characteristic species have their stratigraphic base in the C. pompeckji Chronozone or lower (Fig. 5). In contrast, Sirmiodinium grossii first appears in the lowermost $A$. arcticus Chronozone in Jameson Land. The presence of Crussolia perireticulata, Atopodinium sp. and especially A. haromense in this assemblage indicates that these species appear at a lower stratigraphic level than in nearby Jameson Land. The palynological evidence of the age of assemblage 1 is not very clear, but the presence of $S$. grossii is suggestive of the earliest $A$. arcticus Chron, in accordance with the ammonite data.

Chronostratigraphy. A. arcticus Chronozone, Bathonian.

\section{Assemblage 2}

Ammonite stratigraphy. The palynomorph assemblages were obtained from samples collected between horizons containing ammonite faunas referred to the $A$. arcticus (Jameson Land fauna 9-10) and A. cranocephaloide/C. variabile Chronozones (Fig. 5; Milne Land fauna $\mathrm{M}_{1}$ and younger, Jameson Land fauna 18-21).

Samples. Sample 409455 (409457 barren) from locality 8 in Visdal.

Description. The common occurrence of Gonyaulacysta pectinigera, Aldorfia aldorfensis and Chytroeisphaeridia chytroeides in the sample indicates an earliest C. variabile Chron age, on the basis of correlation with data from Jameson Land.

Chronostratigraphy. C. variabile Chronozone, Bathonian.

\section{Assemblage 3}

Ammonite stratigraphy. The palynomorph assemblage occurs above ammonite-bearing beds referred to the A. cranocephaloide? Chronozone (Milne Land fauna $\mathrm{M}_{1}$ and Jameson Land fauna 18-19).

Samples. Sample 234049 is from a mudstone bed overlying sandstones that yielded an ammonite referred to the A. cranocephaloide? Chronozone at Kosmocerasdal (Fig. 1, locality 1; Callomon \& Birkelund 1980).

Description. This odd assemblage from just one sample is characterised by a flood of Ctenidodinium sp.; this event has not been identified in Jameson Land. The appearance of Evansia granulata supports the age indicated by the ammonite from the underlying beds as it has its first occurrence in the A. cranocephaloide Chronozone in Jameson Land; the underlying A. ishmae Chronozone has not, however, been studied in detail. The minimum age of this assemblage is poorly constrained both on the basis of ammonites and dinoflagellate cysts, but Kallosphaeridium inornatum and Lithodinium cf. reticulata, both of which are present in the assemblage, occur in the uppermost part of the P. koenigi Chronozone in Jameson Land.

Chronostratigraphy. A. cranocephaloide/C. variabile Chronozones, Bathonian.

\section{Assemblage 4}

Ammonite stratigraphy. Sample 255155 was collected from above beds referred to the $A$. cranocephaloide/C. variable Chronozones on the basis of ammonites (Jameson Land fauna 19-21).

Samples. Samples 255148, 255155 and 409556 are from locality 1 at the base of clinoform unit $\mathrm{CB}_{2}$ in Kosmocerasdal and locality 8 in Visdal (Fig. 1). Sample 409556 is from a mudstone horizon above, but close to an ammonite horizon indicating the $A$. cranocephaloide/C. variabile Chronozones. Samples 255155 and 255148 are thought to be from the same horizon but are separated laterally and direct correlation is not possible.

Description. The diversity of the assemblage varies but abundant Chyctroeisphaeridia hyalina, Evansia granulata, Sentusidinium pelionense and Lithodinia cf. reticulata characterise the microflora. The appearance of abundant new species suggests a clear separation in time from the underlying assemblage. Chytriasphaeridia byalina, Atopodinium polygonalis and Evansia granulata become abundant for the first time in the C. calyx Chronozone in 
Jameson Land. Evansia janeae occurs only in the C. calyx Chronozone in Jameson Land in contrast to the occurrence in Milne land. Lithodinia spongiosa is restricted to the C. calyx and C. apertum Chronozones in Jameson Land. A number of characteristic species appearing in this assemblage, viz. Evansia cerebraloides, Paragonyaulacysta sp. (cf. calloviense, Baylei et al.), Kalyptea stegasta, Sentusidinium sp. D (Fensome 1979), Ctenidodinium thulium and Meiourogonyaulax cf. planoseptata, are considered stratigraphically significant but cannot yet be correlated precisely with the succession in Jameson Land.

Chronostratigraphy. C. calyx/C. apertum Chronozones, Bathonian.

\section{Assemblage 5}

Ammonite stratigraphy. None.

Samples. Three samples in stratigraphic succession from the bottomset of clinoform unit $\mathrm{CB}_{3}$ at Kosmocerasdal (locality 1): 409697 , 409698 and 409699.

Description. Abundant new species appear in assemblage 5, again indicating a clear time difference to the underlying assemblage. The assemblage is of high density and diverse in contrast to the earlier assemblages. Sirmiodinium grossii, G. pectinigera, Lithosphaeridium cf. reticulata, Atopodinium sp., Evansia cerebraloides, Ctenidodinium thulium and Sentusidinium sp. D (Fensome 1979) become abundant and Rhynchodiniopsis cladophora, Gonyaulacysta cf. helicoidea, Gonyaulacysta jurassica, Fromea tornatilis, Chytroeisphaeridia chytroeides, Ellipsoidictyum cinctum and Lithodinium jurassica appear for the first time. Approximately $50 \%$ of the species in assemblage 5 occur in the earlier assemblages but not with this high abundance. Only a few of the new species in the assemblage are abundant.

Local correlation. Abundant G. pectinigera has an upper limit in the basal P. koenigi Chronozone in Jameson Land; this limit is recognised within this assemblage. Crussolia perireticulata has an apparent top in the C. nordenskjoeldi Chronozone in Jameson Land and this may also be recognised within this assemblage. Chytroeisphaeridia chytroeides is almost wholly restricted to this interval, and is similarly present or abundant in the C.nordenskjoeldi Chronozone in Jameson Land. Atopodinium polygonalis is only recorded in the C. calyx and C. apertum Chronozones in Jameson land, whereas Paraevansia brachythelis is recorded in the C. apertum and C. nordenskjoeldi Chronozones. A suite of species which are uncommon in the assemblage have their stratigraphic tops in the basal P. koenigi Chronozone in Jameson Land.
Chronostratigraphy. C. nordenskjoeldi - earliest P. koenigi Chronozone, Lower Callovian.

\section{Assemblage 6}

Ammonite stratigraphy. The assemblage occurs beneath ammonite-bearing beds referred to the $P$. athleta Chronozone.

Samples. Two samples $(255153,255154)$ in the basal strata of the Kap Leslie Formation in Kosmocerasdal (locality 1).

Description. The assemblage is characterised by medium diversity and low abundance. Chytroeisphaeridia hyalina is the only abundant species accompanied by Pareodinia prolongata in one sample. Only few stratigraphically new species appear in the assemblage suggesting stratigraphic proximity to the underlying Assemblage 5.

Local correlation. The ammonite and dinoflagellate stratigraphy in the Jameson Land Basin is not well correlated in the interval between the $S$. calloviense and $P$. athleta Chronozones (fauna $\mathrm{M}_{2}$ ), but the distribution of dinoflagellate cysts in both chronozones is fairly well known. In Jameson Land, Chytroeisphaeridia byalina occurs in abundance in the $S$. calloviense Chronozone, coincident with the last continuous occurrence of Gonyaulacysta pectinigera. The only abundant dinoflagellate recorded by Fensome (1979) from the S. calloviense Chronozone of Jameson Land was Valensiella dictydia (15-30\% of the assemblage), associated with Gonyaulacysta pectinigera and Valensiella ovula (5-15\% of the assemblage). $V$. dictydia and $V$. ovula have been recorded previously from these strata (Piasecki 1980; Smelror 1988) but were not observed in the present samples. Fensome (1979) also described Paragonyaulacysta sp. (possibly equivalent to Paragonyaulacysta retiphragmata) from this chronozone and his species is recorded here. The assemblage is correlated with the S. calloviense Chronozone.

Chronostratigraphy. S. calloviense Chronozone, Lower Callovian.

\section{Assemblage 7}

Ammonite stratigraphy. None.

Samples. Samples (255147, 255149-255151, 409543, 409544, 409550, 409558) from the bottomset of clinoform unit $\mathrm{CB}_{4}$, in the uppermost Charcot Bugt Formation in Visdal (localities 8, 9, 11)

Description. The dinoflagellate assemblage is dominated by Gonyaulacysta jurassica, Rhynchodiniopsis cladophora, Liesbergia 
scarburghensis, Rigaudella aemula and Pareodinia stegasta at successively higher stratigraphic levels.

Local correlation. The presence of Wanaea thysanota in association with Rigaudella aemula, Liesbergia scarburghense and Scriniodinium crystallinum corresponds to the interval between ammonite faunas $\mathrm{M}_{4}$ and $\mathrm{M}_{5}$ of Milne Land (C. cordatum to lowermost $C$. densiplicatum Chronozones) in the fine-grained Kap Leslie Formation. The samples in the same bed towards the east show the top of abundant Rigaudella aemula, followed by an acme of Pareodinia stegasta. These two events correspond to the level between Milne Land ammonite faunas 6 and 7, indicative of the upper $C$. densiplicatum Chronozone.

Chronostratigraphy. C. cordatum to C. densiplicatum Chronozones, Lower-Middle Oxfordian.

\section{Assemblage 8}

Ammonite stratigraphy. None.

Samples. Samples $(409546,409551,409559)$ from the basal part of the Kap Leslie Formation onlapping the Charcot Bugt Formation, from the east towards the west (Fig. 1, localities 5, 12).

Description. Dinoflagellate cysts from two samples of the basal mudstones (409546 is effectively barren) reflect the stratigraphic onlap. The common presence of Ambonosphaera calloviana and Dingodinium sp. indicate a level corresponding to Milne Land ammonite fauna 10 (upper $A$. glosense Chronozone), and in the succeeding sample, Epiplosphaera bireticulata and Stephanelytron redcliffense appear and indicate the stratigraphic level above Milne Land ammonite fauna 10 (A. glosense to A. serratum Chronozones).

Chronostratigraphy. A. glosense to A. serratum Chronozones, Upper Oxfordian. 